\title{
Stem cells in clinical practice: applications and warnings
}

Daniele Lodi ${ }^{1}$, Tommaso lannitti ${ }^{2^{*}}$, Beniamino Palmieri ${ }^{3}$

\begin{abstract}
Stem cells are a relevant source of information about cellular differentiation, molecular processes and tissue homeostasis, but also one of the most putative biological tools to treat degenerative diseases. This review focuses on human stem cells clinical and experimental applications. Our aim is to take a correct view of the available stem cell subtypes and their rational use in the medical area, with a specific focus on their therapeutic benefits and side effects. We have reviewed the main clinical trials dividing them basing on their clinical applications, and taking into account the ethical issue associated with the stem cell therapy.

Methods: We have searched Pubmed/Medline for clinical trials, involving the use of human stem cells, using the key words "stem cells" combined with the key words "transplantation", "pathology", "guidelines", "properties" and "risks". All the relevant clinical trials have been included. The results have been divided into different categories, basing on the way stem cells have been employed in different pathological conditions.
\end{abstract}

\section{Introduction}

The word "stemness" defines a series of properties which distinguish a heterogeneous variety of cell population. However, in the absence of a current consensus on a gold standard protocol to isolate and identify SCs, the definition of "stemness" is in a continuous evolution [1-3].

Biologically, stem cells (SCs) are characterized by selfrenewability [4], that is the ability not only to divide themselves rapidly and continuously, but also to create new SCs and progenitors more differentiated than the mother cells. The asymmetric mitosis is the process which permits to obtain two intrinsically different daughter cells. A cell polarizes itself, so that cell-fate determinant molecules are specifically localized on one side. After that, the mitotic spindle aligns itself perpendicularly to the cell axis polarity. At the end of the process two different cells are obtained [5-7].

SCs show high plasticity, i.e. the complex ability to cross lineage barriers and adopt the expression profile and functional phenotypes of the cells that are typical of other tissues. The plasticity can be explained by transdifferentiation (direct or indirect) and fusion.

\footnotetext{
* Correspondence: tommaso.iannitti@gmail.com

${ }^{2}$ Department of Biological and Biomedical Sciences, Glasgow Caledonian University, Glasgow, UK

Full list of author information is available at the end of the article
}

Transdifferentiation is the acquisition of the identity of a different phenotype through the expression of the gene pattern of other tissue (direct) or through the achievement of a more primitive state and the successive differentiation to another cell type (indirect or dedifferentiation). By fusion with a cell of another tissue, a cell can express a gene and acquire a phenotypic element of another parenchyma [3].

SCs morphology is usually simpler than that one of the committed cells of the same lineage. It has often got a circular shape depending on its tissue lineage and a low ratio cytoplasm/nucleus dimension, i.e. a sign of synthetic activity. Several specifics markers of general or lineage "stemness" have been described but some, such as alkaline phosphatase, are common to many cell types [1,8-11].

From the physiological point of view, adult stem cells (ASCs) maintain the tissue homeostasis as they are already partially committed. ASCs usually differentiate in a restricted range of progenitors and terminal cells to replace local parenchyma (there is evidence that transdifferentiation is involved in injury repair in other districts [12], damaged cells or sustaining cellular turn over [13]). SCs derived from early human embryos (Embryonic stem cells (ESCs)), instead, are pluripotent and can generate all committed cell types [14,15]. Fetal stem cells (FSCs) derive from the placenta, membranes, 
amniotic fluid or fetal tissues. FSCs are higher in number, expansion potential and differentiation abilities if compared with SCs from adult tissues [16]. Naturally, the migration, differentiation and growth are mediated by the tissue, degree of injury and SCs involved. Damaged tissue releases factors that induce SCs homing. The tissue, intended as stromal cells, extracellular matrix, circulating growth and differentiating factors, determines a gene activation and a functional reaction on SCs, such as moving in a specific district, differentiating in a particular cell type or resting in specific niches. These factors can alter the gene expression pattern in SCs when they reside in a new tissue [17].

Scientific research has been working to understand and to indentify the molecular processes and cellular cross-talking that involve SCs. Only with a deep knowledge of the pathophysiological mechanism involving SCs, we might be able to reproduce them in a laboratory and apply the results obtained in the treatment of degenerative pathologies, i.e. neurological disorder such as Parkinson's disease (PD), Alzheimer's disease (AD), Huntington's disease, multiple sclerosis [18], musculoskeletal disorder [19], diabetes [20], eye disorder [21], autoimmune diseases [22], liver cirrhosis [23], lung disease [24] and cancer [25].

In spite of the initial enthusiasm for their potential therapeutic application, SCs are associated with several burdens that can be observed in clinical practice. Firstly, self-renewal and plasticity are properties which also characterize cancer cells and the hypothesis to lose control on transplanted SCs, preparing a fertile ground for tumor development, is a dangerous and unacceptable side effect [26,27]. Secondly, in case of allogenic SCs graft, several cases of immunorejection or graft versus host disease [28] are reported, with a necessary immunosuppressive treatment to avoid immune response against the transplant and the consequent risk of infections. Finally, to succeed in ESCs cultures, it is necessary to manipulate and to reproduce embryos for scientific use, but the Catholic World identifies this stage of the human development with birth and attributes embryos the same rights [29].

\section{Stem Cells Types}

SCs are commonly defined as cells capable of self-renewal through replication and differentiating into specific lineages. Depending on "differentiating power", SCs are divided into several groups. The cells, deriving from an early progeny of the zygote up to the eight cell stage of the morula, are defined as "totipotent", due to their ability to form an entire organism [30]. The "pluripotent" cells, such as ESCs, can generate the tissues of all embryonic germ layers, i.e. endoderm, mesoderm, and ectoderm, while "multipotent" cells, such as ASCs, are capable of yielding a more restricted subset of cell lineages. Another type of SCs classification is based on the developmental stage from which they are obtained, i.e. embryonic origin (ESCs) or postnatal derivation (ASCs) [3].

\section{Embryo-derived stem cells}

A zygote is the initial cell originating when a new organism is produced by means of sexual reproduction. Zygotes are usually produced by a fertilization event between two haploid cells, i.e. an ovum from a female and a sperm cell from a male, which combine to form the single diploid cell [31].

The blastocyst is the preimplantation stage in embryos aged one week approximately. The blastocyst is a cave structure compound made by the trophectoderm, an outer layer of cells filling cavity fluid and an inner cell mass (ICM), i.e. a cluster of cells on the interior layer [32-35].

Embryonic cells (EC, epiblast) are contained in the ICM and generate the organism, whereas the surrounding trophoblast cells contribute to the placental chorion. Traditionally, ECs are capable of a self-renewal and differentiation into cells of all tissue lineages [15], but not into embryonic annexes as such zygote. ECs can be cultured and ESCs can be maintained for a long time (1-2 years with cell division every $36-48$ hours) in an undifferentiated phenotype $[10,33,36]$ and which unchanged properties. ECs can be isolated by physical micro dissection or by complement-mediated immune dissection. ECs are preserved through fast freeze or vitrification techniques to avoid an early natural differentiation [37-39]. Culturing ESCs requires a special care, in fact, under SCs, a feeder layer of primary murine fibroblast is seeded in a permanent replication block that sustains continuously undifferentiated ESCs [14]. ESCs are maintained for a long time in culture to obtain a large pool of undifferentiated SCs for therapeutic and research applications. In contrast, somatic cells and mesenchimal stem cells (MSCs) have finite replicative lifespan after which they can no longer divide and are said to have reached a proliferative senescence [40]. The replicative lifespan of cells depends on the cell type, donor's species, and donor's age, but it is directly related to telomerase activity [41-44]. Telomerase is an enzyme which adds specific short sequences to chromosomes ends, aiming at preserving chromosome length and supporting the ongoing cell division [42]. Telomerase activity is decreased by committing and, as a result, it is characteristically high in ESCs, intermediate in haematopoietic stem cells (HSCs), and variable, or even absent, in somatic cells $[3,42]$.

\section{Fetal stem cells}

FSCs are multipotent cells with the same functional properties of ASCs, but they locate in the fetal tissue 
and embryonic annexes. Indeed, further analyses are necessary to investigate whether ASCs are the same present in the tissue. FSCs have been subdivided into haemopoietic ones, located in blood, liver, bone marrow (BM), mesenchymal ones located in blood, liver, BM, lung, kidney and pancreas, endothelial ones found in BM and placenta, epithelial ones located in liver and pancreas and neural ones located in brain and spinal cord [45]. Obviously, the only source of FSCs, relatively feasible and safe for fetus, is fetal blood [46]. Nowadays a routine procedure for fetal diagnosis and therapy, which are the most diffuse techniques to harvest FSCs, is ultrasound guided accession to fetal circulation [45].

\section{Adult stem cells}

ASCs are partially committed SCs localized in specific stromal niches. ASCs can be obtained from the mesodermal tissues such as BM [1,47], muscle [48], adipose tissue [49], synovium [50] and periosteum [51]. SCs have been also isolated from the tissues of endodermal lineages such as intestine [52] and from the ectodermal tissues including skin [53], deciduous teeth [54] and nerve tissue $[8,9,55,56]$. ASCs originate during ontogenesis and remain in a marginal area in a quiescent state as the local stimuli induce their cycle recruitment and migration. In fact, niche microenvironment, with physical contact and chemical dialogue among SCs, stromal cells and matrix, induce ASCs differentiation and selfrenewal $[57,58]$.

Probably, for documented plasticity and easy extraction, several ASCs types, such as HSCs, adipose tissuederived stromal cells (ADSCs) and derived MSCs, have had and have a historical importance. HSCs are well characterized cells of mesodermal origin deriving prevalently from BM, in particular near endosteal bone surface and sinusoidal endothelium and from peripheral blood. Traditionally HSCs generate all mature blood cell types of the hematolymphatic system including neutrophils, monocytes/macrophages, basophils, eosinophils, erythrocytes, platelets, mast cells, dendritic cells, and B and T lymphocytes. More recently, HSCs have shown to display remarkable plasticity and can apparently differentiate into several non-hemolymphatic tissue lineages [3]. The identification and isolation of HSCs is possible with immune capture of CD34, a surface protein that distinguishes SCs from other hematopoietic cells [59]. HSCs are at the base of BM transplant procedures, i.e. myeloablation or adiuvant therapy where HSCs are infused in the recipient [60].

MSCs originally derive from BM, $[1,8,47]$ but they have been isolated from other tissues, such as adipose tissue, periosteum, synovial membrane, synovial fluid (SF), muscle, dermis, deciduous teeth, pericytes, trabecular bone, infrapatellar fat pad, and articular cartilage [1,19,47,61-68].
They are generally restricted to forming only mesodermalspecific cell types such as adipocytes, osteoblasts, myocytes and chondrocytes, but several MSCs are able to differentiate in cells of the three embryonic germ layers [69]. Several of these studies report the differentiation of MSCs into various tissue lineages in vitro and the repair or "engraftment" of the damaged organs in vivo, such as bone tissue repair and immune system reconstruction, but they are even able to differentiate in endothelial cells and contribute to revascularization of the ischemic tissue $[3,70,71]$. In particular, recent studies show that cultured MSCs secrete various bioactive molecules which have got anti-apoptotic, immunomodulatory, angiogenic, antiscarring and chemo-attractant properties, providing a basis for their use as tools to create local regenerative environments in vivo [72].

\section{Umbilical cord stem cells}

In the umbilical cord, we can find two types of SC sources, i.e. the umbilical cord epithelium (UCE), derived from the amniotic membrane epithelium and the umbilical cord blood (UCB) [73]. Although its general architecture significantly differs from the mammalian epidermis, UCE expresses a cytokeratin pattern similar to human epidermis $[74,75]$. UCE is able to form a stratified epithelium when seeded on fibroblast populated collagen gels $[76,77]$. It has been demonstrated that UCE is an important source of the human primary keratinocytes and it is able to recreate the epidermis for dermatological application [78]. In UCB we can find two different types of SCs, i.e. hematopoietic (UC-HS) and mesenchymal (UC-MS). Although UCB SCs are biologically analogous to their adult counterpart, it has been pointed out that UCB cells are characterized by a higher immunological tolerance than their adult counterpart [79]. Indeed UC-MS can produce cytokines which facilitate grafting in the donor, in vitro SC survival and it is more efficient than BM MSC graft [80].

\section{Risks And Obstacles To Stem Cells Application In Clinical Practice \\ Risks}

SC graft induces therapeutic and side effects. A specific evaluation of the side effects is needed to decide if a cure can be adopted in medical practice. Indeed, scientific research has to outline the severity of undesired effects, their frequency in treated subjects and the possibility to avoid, reduce or abate them. The major limitations to the success of HSC transplantation (HSCT) are respiratory complications and graft versus host disease. Lung dysfunction occurs in up to $50 \%$ of the subjects after HSCT, and pulmonary complications are among the most common causes of morbidity and mortality after this procedure. 
Obliterative bronchiolitis $(\mathrm{OB})$ is a multifactorial process involving both alloimmunologic and nonalloimmunologic reactions as the heterogeneous histopathologic findings and clinical course suggest. Since the occurrence of OB has been closely associated with GVHD, it has been hypothesized that $\mathrm{OB}$ is mediated, partially, by alloimmunologic injury to host bronchiolar epithelial cells [81-83]. Usually, OB develops as a late complication, i.e. after the first 100 days, of HSCT. The OB onset is usually 6-12 months post-transplant, with the clinical seriousness ranging from asymptomatic severity to a fulminant and fatal one. The pathogenesis of the disease is believed to primarily involve the interplay among immune effectors cells that have been recruited from the lung and cells resident in the pulmonary vascular endothelium and interstitium. This complex process results in the loss of type I pulmonary epithelial cells, a proliferation of type II cells, the recruitment and proliferation of endothelial cells and the deposition of the extracellular matrix. In response to the pattern of injury, cytokines are released from immune effectors cells and lung cells, i.e. macrophages, alveolar epithelial, and vascular endothelial cells, and they can stimulate the fibroblast proliferation and increase the synthesis of collagen and extracellular matrix proteins. The result is the large deposition of collagen and granulation tissue in and around the bronchial structures, with the partial or complete small airway obliteration. Clinical data suggest that nonalloimmunologic inflammatory conditions, such as viral infections, recurrent aspiration, and conditioning chemoradiotherapy may also play a role in the pathogenesis of OB after HSC transplantation $[84,85]$. Bronchiolitis obliterans organizing pneumonia (BOOP) is a disorder involving bronchioles, alveolar ducts, and alveoli, whose lumen becomes filled with buds of granulation tissue, consisting of fibroblasts and an associated matrix of loose connective tissue. It derives from the proliferative type, and it generally includes mild inflammation of the bronchiolar walls. In contrast to $\mathrm{BO}$, there is no prominent bronchiolar wall fibrosis or bronchiolar distortion [86]. The involvement of an alloimmunologic reaction can be considered, although the pathogenesis of BOOP following HSCT is poorly understood. In animal studies, BOOP develops after a reovirus infection. A significant role for $\mathrm{T}$ cells and Th1-derived cytokines, including interferon- $\alpha$, is implicated in the development of disease [87]. Indeed, T-cell depletion prevents from $\mathrm{BO}$ and BOOP after allogeneic hematopoietic SC transplantation with related donors [88]. A reported case, following syngeneic BM transplantation, suggests that BOOP is not always the result of an allogeneic immune response [89]. In other nonHSCT settings, BOOP has been seen in association with infection, drugs, radiation therapy, and a number of connective tissue disorders [90]. It has also been shown that the 2-year cumulative incidence of late-onset noninfectious pulmonary complications (LONIPC, including $\mathrm{BO}$ and $\mathrm{BOOP}$ ) has been $10 \%$ in 438 patients undergoing HSCT. Moreover, the survival rate at 5 years has been significantly worse in affected subjects than in unaffected ones [91].

Graft versus host disease (GVHD) is a frequent and lethal complication of HSCT that limits the use of this important therapy. On the basis of pathophysiology and appearance, GVHD is classified in acute and chronic one [92]. Acute GVHD occurs prior to day 100 after transplant and it consists in an enhanced inflammatory/ immune response, mediated by the competent donor's lymphocytes, infused into the recipient, where they react against an environment perceived as a foreign one. The process is amplified through the tissue release of molecules which stimulate the donor's lymphocytes. This apparently contradictory phenomenon is simply a physiological reaction of the damaged tissue to the disease which has led to the transplant therapy [93]. Acute GVHD presents clinical manifestations in the skin, i.e. maculopapular rash, which can spread throughout the body, dyskeratosis (in severe cases the skin may blister and ulcerate) [94], in the gastrointestinal tract, i.e. diarrhea, emesis, anorexia, abdominal pain, mucosal ulceration with bleeding, luminal dilatation [95], and in the liver, i.e. same liver dysfunction of veno-occlusive disease, drug toxicity, viral infection, sepsis, or iron overload [96]. Chronic GVHD is the major cause of late non-relapse death following HCT [97]. However, chronic GVHD pathophysiology is not completely understood. Probably, thymus atrophy or dysfunction, which can develop after pharmacological preparation of transplant, play a major role in chronic GVHD manifestation. This fact leads to a peripheral tolerance decrease and to an increase in the number of autoreactive $\mathrm{T}$ lymphocytes. Autoreactive T lymphocytes lead to an interferon gamma mediated increase in the collagen deposition and fibrosis, a characteristic feature of chronic GVHD [97,98]. The manifestations of chronic GVHD are protean and often of an autoimmune nature. Many districts are involved, i.e. skin with dyspigmentation, alopecia, poikiloderma, lichen planus-like eruptions or sclerotic features, nails with nail dystrophy or loss, the mouth with xerostomia, ulcers, lichen-type features, restrictions of mouth opening from sclerosis, eyes with dry eyes, sicca syndrome, cicatricial conjunctivitis, muscles, fascia and joints with fasciitis, myositis, or joint stiffness from contractures, the female genitalia with vaginal sclerosis, ulcerations, the gastrointestinal tract with anorexia, weight loss, esophageal web or structures, liver with jaundice, transaminitis, lungs with restrictive or obstructive defects on pulmonary function tests, 
bronchiolitis obliterans, pleural effusions, kidneys with nephrotic syndrome (rare), heart with pericarditis and bone marrow (thrombocytopenia, anemia, neutropenia) $[92,99,100]$.

Hepatic veno-occlusive disease (VOD) is another recurrent complication after SC transplantation. VOD is a condition in which some of the small hepatic veins are blocked, in this case, by cells. It is a complication of high-dose chemotherapy given before a BM transplant and it is marked by weight gain, due to fluid retention, increased liver size, and raised levels of bilirubin in the blood [101,102]. VOD is more frequent in children undergoing SC transplantation [103].Two hundred and forty four HSCTs have been evaluated and it has been found that VOD had appeared in $11 \%$ of them. It has been identified that risk factors for VOD are age $<6.7$ years, type of VOD prophylaxis, and busulphan-containing conditioning regimens [104]. Interesting results have been obtained in VOD treatment by oral defibrotide [105] and combination of intravenous heparin, oral glutamine and ursodiol [106].

\section{Obstacles and possible solutions}

The compatibility between the recipient and the graft is the main problem that must be faced off when a medical group decides to transplant organs, tissues or cells successfully. In SCT, the immunorejection also represents an important obstacle. If autogenous cells are available, immunorejection can be bypassed. In fact, common clinical practice is to harvest autogenous MCSs, expand them in culture, avoiding microorganism contamination, and store the obtained cell population before implantation [9].

Interestingly, allogenic MCSs transplant, obviously applied in emergency situations, such as spinal cord injury or myocardial infarction, demonstrates high success rates. A tolerance of allogenic MCSs seems to be induced by the same grafted cells. Indeed, MCSs inhibit $\mathrm{T}$ cell proliferation and maturation through direct cellcell effects and by secretion of soluble factors $[107,108]$.

Allogenous EC transplantation is not immunotolerated as MSCs graft. Therefore, avoiding the EC immunorejection, several strategies are being developed. Somatic cell nuclear transfer (SCNT) is currently the most promising of them. SCNT consists in the enucleation of the donor's oocytes and the renucleation of them with nuclei taken from the patient's somatic cells. The created cells are tolerated because they express major histocompatability complex (MHC) of the recipient. The disadvantages of SCNT include the creation and destruction of embryos and the current inability to apply the technology in autoimmune diseases [109]. In order to avoid autoimmune rejection, some elaborate methods, such as gene therapy, are under investigation $[3,110]$.
ESCs are characterized by genetic instability and imprinting genes dysregulation [111]. Indeed, their transplantation in rodents is associated to higher risk of malignant transformations, such as teratomas or teratocarcinomas [112-114], although the tumorigenic potential of ESC seems to be greatly reduced when the cells are predifferentiated in vitro before implantation [115]. The graft of ESCs must be preceded by an accurate functional characterization to distinguish partially transformed and potentially oncogenic clones and normal cells [116].

\section{Medical tourism}

In developing countries some doctors are treating patients with ASC without waiting for clinical trials to validate the safety of using them for health problems [117].

In treatments, involving the use of ASC, the cells are injected into the blood, lumbar region, or damaged tissue. The only treatments using ASC that are proven by clinical trials, are concerned with blood disorders, bone marrow transplantation and rare immune deficiencies. Several cases of patients, who developed serious side effects following SC transplantation, such as brain tumors, after injections of fetal neural SC, or meningitis have been reported [118].

A Google search, using the key words "stem cell therapy" or "treatment", has outlined the range of treatments being offered directly to consumers. Websites generally describe therapies as safe, effective, and ready for routine use in a wide variety of conditions. In contrast, the published clinical evidence has been unable to support the use of these therapies for the routine disease treatment. Patients must receive sufficient and appropriate information and fully understand the risks. Clinics must also contribute to public expectations without exceeding what the field can reasonably achieve. However, this interpretation is subject to the following limitations: information, available from websites, could not be indicative of the information actually shared with patients during their clinical encounters; the aggregate data, collected from a heterogeneous group of clinics, could not be used to evaluate the claims of any particular clinic; and finally, the accuracy of websites' claims has not been tested directly by analyzing actual outcome data. Instead, there is a lack of high quality evidence supporting SC clinics' claims. Even supposing that clinics have indeed observed successful recovery from chronic disease post-treatment, a lack of good evidence precludes a valid or precise inference that the observed improvement is attributable to the interventions. If, in fact, the interventions had not been effective, then the patients would have been subjected to inappropriate risks and exaggerated financial burden $[119,120]$. 


\section{Possible Clinical Uses}

\section{Autoimmune disease}

\section{Rheumatoid arthritis and juvenile idiopathic arthritis}

Rheumatoid arthritis (RA) is the progressive and irreversible erosion of the cartilage tissue of joint with the consequent loss of mobility, pain and reduction in the quality of life. Probably, RA and juvenile idiopathic arthritis (JIA) are caused by failure of tolerance and immune response against joint tissue antigens and aptens with abundant release of inflammatory cytokines and autoantibody $[121,122]$. Standard therapy encloses nonsteroidal medications with slow addition of traditional disease-modifying anti-rheumatic drugs (DMARDs) or intra-articular corticosteroid injections, but the remission rate is only about 15\% [123].

Several clinical trials have been conducted to treat RA and JIA with autologous HSCs transplantation (AHSCT).

A significant response has been obtained in most subjects in a study involving 76 patients with severe RA which were resistant to conventional therapies and submitted to AHSCT. Although the disease has not been cured, recurrent or persistent disease activity has been controlled, in some cases, with common antirheumatic drugs [124]. A trial, involving 33 patients with severe, refractory RA, randomly submitted to either AHSCT or selected CD34+ infusion, has not shown any advantage with antigen selection, but it has confirmed immunomodulatory action of HSC in joint microenvironment [125]. A successfully HSCT protocol has been proposed to treat severe JIA, harvest BM, select positive SCs, deplete $\mathrm{T}$ cells, re-infuse the cells and administer antiviral drugs and immunoglobuline until the immune system returns to full competence to avoid frequent infection [126].

\section{Systemic lupus erythematosus}

Systemic lupus erythematosus (SLE) is a multi-system, inflammatory, autoimmune disease, caused by BM microenvironment dysfunction and consequently a marked reduction of number and proliferative capability of HSCs with a hyperproduction of immunocomplex. Cells CD34+ undergo an elevated apoptosis rate. SLE includes nephritis, serositis, pneumonitis, cerebritis, vasculitis, anti-phospholipid antibody syndrome with venous and vascular thrombi, arthalgias, myalgias, cutaneous symptoms [127]. Usually SLE is aspecifically treated with non-steroidal anti-inflammatory drugs, antimalarials, corticosteroids and cytotoxic agents. However, every drug involves severe side effects and frequent relapses [128].

AHSCT has reduced the number of apoptotic CD34+ cells pre-treatment [22]. In the last decade, contrasting results have been reported in literature. AHSCT has been performed on 15 patients with severe SLE with a general positive outcome. Only two subjects have had a recurrence of symptoms [129]. However, it has been reported a lower disease free rate and high mortality [130]. Further trials are required, but it seems probable that HSCT can be used not with a curative intent, but to mitigate the disease impact towards a more drug sensitive type. However, it should be reserved only for those patients with persistence of organ-threatening SLE, despite the standard aggressive therapy [131].

\section{Multiple sclerosis}

Multiple Sclerosis (MS) is a life-threatening, physically and psychologically debilitating autoimmune disease

(AD), mediated by $\mathrm{T}$ cells triggered against structural components of myelin and consequent degenerative loss of axon in the central nervous system (CNS). In fact, the nerve atrophy progressively reduces the electrical signalling neurons muscles and related mobility. The inflammatory reaction is an important component of MS physiopathology and the conventional treatments aims at reducing it in order to cure or postpone course disease [132,133]. Two types of MS can be identified: primary progressive MS (PPMS), generally resistant to treatment and without amelioration, and secondary progressive MS (SPMS) with episodic relapse and improvement [134].

As gold standard therapy efficiently delays MS progression for many years, AHSCT have been performed on patients who do not respond to conventional therapies, and consequently the results have not been encouraging and, in several cases, they have taken a turn for the worse [135]. Furthermore, graft exposes patients to infection risks, localized toxicity or autoimmune diseases [136,137]. However, it has been reported a reduction of CNS inflammation with a stabilization of the disease in patients aged less than 40 years [136]. A plastic conversion of HSC-derived cells, to replace damage neurons, has been hypothesized [138].

\section{Systemic sclerosis}

Systemic sclerosis (SSc) is a multisystem, rare disorder characterized by cutaneous and visceral (pulmonary, cardiac, gastrointestinal and renal) fibrosis as a consequence of $\mathrm{T}$ cell activation, autoantibody production, cytokine secretion and excessive collagen deposition. Patients with the diffuse variant, who have extensive skin and early visceral involvement, have a poor outcome with a 5 -year mortality which is estimated at $40-50 \%$ in 5 years [139]. The therapy for the SSc is far from being perfect. At present, the best results are obtained with the combination of cyclophosphamide (CY) and angiotensin [140].

It has been demonstrated that AHSCT improves the skin flexibility and stabilizes the pulmonary involvement [141-146]. 
Farge et al. have compared two studies with conflicting results. The first describes a long time remission rate of $80 \%$ (partial or complete) on 57 patients, and the majority of the subjects have presented a general improvement of pre-AHSCT clinical condition. The second study, instead, shows a higher reactivation rate (50\%). Interestingly, AHSCT can extend the short life expectancy of patients with severe SS [147].

Ultimately, priming regimens, i.e. a disease progression and transplant procedure, that is transplanted-related complication, have been associated to high mortality rates $(27 \%)$ [143].

\section{Crohn's disease}

It is an incompletely known autoimmune disease characterized by the gastrointestinal loss of immune tolerance caused by overactive $\mathrm{T}$-helper 1 response. The environmental agents and genetic factors are also involved. Sometimes the disease can be controlled by immunosuppressive drugs, antibodies and surgical intervention [148]. AHSCT has proved safe and can be able to induce and maintain remission in previously refractory patients affected by Crohn's disease $[149,150]$.

By combining AHSCT with CY, a clinical remission with a disappearance of diarrhea, and a reduction in the abdominal pain and activity have been obtained [151].

\section{Autoimmune cytopenias}

In immune thrombocytopenia purpura (ITP), the platelets are removed from blood by autoantibodies and the effects are thrombocytopenia and bleeding. Usually, ITP cases are responsive to high doses of immunosuppressors; nevertheless this treatment exposes them to myelosuppression risks. HSCT can accelerate the reestablishment of the hematological parameters, while the number of autoimmune cells in the body decreases [152]. An American study has showed the efficacy of a combined therapy of $\mathrm{CY}$ and AHSCT in chronic refractory ITP treatment. The majority of patients show a long term response, suggesting that SCs can accelerate the hematological re-balance compared with classic immunotherapy [153]. A study by European Bone Marrow Transplantation (EBMT) reports the treatment of 12 cases of ITP with AHSCT. However, the responses to treatment have varied from a transient response to a continuous remission or even death related to transplantation [154]. Immune haemolytic anemia (IHA) is a hematologic disease characterized by an early destruction of erythrocytes due to an autoreaction of antibodies or complement against the membrane protein [155-157]. The few reports available do not permit to gain definitive conclusions. It has been suggested that the association between the AHSCT and immunosuppressive therapy can be an effective treatment for IHA [158]. However it has also been showed a high failure rate or even death after HSCT [159].

\section{Diabetes Mellitus}

Type I diabetes mellitus (DM) results in a cell-mediated autoimmune attack against insulin-secreting pancreatic $\beta$-cells. Insulin regulates glucose homeostasis and, in particular, it reduces glycemia when glucose exceeds in blood. Glucose accumulation, which is typical of diabetes, damages blood vessels causing the decrease of cell perfusion. Other complications are diabetic neuropathy, consisting of a gradual loss of hand, foot and limb mobility caused by nerve degeneration, retinopathy, characterized by loss of vision and blindness for lightsensitive retina atrophy, nephropathy with a loss of removing wastes and excess water and urinary tract infection with a glucose rich urine which favours bacteria proliferation. The common therapy consists in the chronic introduction of exogenous insulin to restore glucose homeostasis, although resistance to this therapy has been observed [160-163]. SC transplantation can rehabilitate pancreatic islets and reintroduce physiological secretion of human insulin.

AHSCT improves $\beta$-cells function and frequently decreases the exogenous insulin need [20] or induces a persistent insulin independence and normal glycemic control when grafted in type $1 \mathrm{DM}$ subjects [164].

Combining CY with AHSCT, an insulin-free period is achieved [22]. In particular it has been proposed a synergic action of CY and AHSCT to explain exogenous insulin independence. This has been shown in the first successful Polish attempt to achieve remission in the early phase of type 1 diabetes mellitus following immunosuppressive treatment and the subsequent AHSCT. The method involves the destruction of the patient's immune system and also the autoimmune process which is the main pathomechanism in type 1 diabetes mellitus. As soon as the autoaggressive mechanism is stopped, pancreatic cells might be able to resume secretion of sufficient amounts of insulin to maintain normal glucose level [165]. Allotropic human adipose tissue derived, insulin-making mesenchymal SCs (h-AD-MSC) have been transfused with unfractionated cultured BM in insulinopenic DM patients without side effects. Furthermore, an appreciable insulin requirement decrease has been observed [166].

\section{Neurological disorders \\ Amyotrophic lateral sclerosis}

Amyotrophic lateral sclerosis (ASL) is caused by the progressive death of central and peripheral motor neurons. The subjects affected by ALS show a severe motor dysfunction. In several cases the mutation of the superoxide dismutase gene is inherited, but often its origin is unknown. ALS is not a typical AD because autoimmune and inflammatory abnormalities are not an etiological cause of the disease, even if they influence its 
progression. The therapeutic strategy, used for ALS, is intended to protect neurons from degeneration and to stimulate cell regeneration. At the moment, no drug treatment restores the neural cells. SCs therapy is a promising strategy that can combine neuroprotection with the recovery of the neuromotor function [167].

Intrathecal injection of selected HSC or MSC have resulted safe and have afforded a partial neurological function improvement in patients with severe ALS $[168,169]$.

Ex vivo expanded AHSC spinal injection, in patients with severe impairment of the lower limb by ALS, has also showed cell number-related improvement of general condition, i.e. a deceleration of the leg muscular strength loss and a respiratory function decline. Side effects, such as intercostal pain or dysesthesia have only been slight and reversible, but they sometimes persist after 2 years from treatment [170].

AHSCT into the frontal motor cortex in ALS patients has delayed the disease progression and has improved the quality of life [171].

Many cases of ALS patients, treated with autologous SCs (mesenchymal and hematopoietic) and injection (intraspinal thoracic or in motor cortex), have been reported. A deceleration of forced vital capacity linearly declines and an improvement in functionality has been described, probably due to an immunomodulatory effect [172].

\section{Parkinson's disease}

Parkinson's disease (PD) is a debilitating neurodegenerative disorder caused by selective and gradual loss of nigrostriatal dopamine-containing neurons [112]. Dopaminergic neurons are localized in the substantia nigra pars compacta and project on to striatum. A degeneration of these cells leads to neural circuit anomaly in the basal ganglia that regulate movement. The main symptoms are rigidity, bradykinesia, tremor and postural instability [173]. Pharmacological treatments, such as levodopa/carbidopa, dopamine agonists, MAO-B inhibitors, and COMT inhibitors, are effective to control PD symptoms but they are unable to stop neural degeneration and replace dead cells [174]. In this context SCs seem to be promising since they can stimulate the recovery of neuromotor function. PD patients, who had received unilaterally striatum human embryonic mesencephalic tissue implants twice, have showed movement improvements (different degrees) and DOPA (dopamine precursor) increased levels $[175,176]$. Symptoms and Ffluorodopa (marked analogous) uptake have significantly improved in PD patients younger than 60 [177].

Bilateral fetal nigral graft, in PD patients, has also resulted safe and quite effective. Fluorodopa uptake has increased, but in about half of the patients dyskinesia has remained unchanged $[178,179]$.

\section{Spinal cord lesions}

Spinal trauma can break ascending and descending axonal pathways with consequent loss of neurons and glia, inflammation and demyelination. Depending on the injury site, functional effects, induced by cellular damage, are inability of movement, sensorial loss and/or lack of autonomic control. No therapies for spinal trauma exist. However, interesting results have been obtained with SCs transplantation [112].

Based on the discovery that olfactory mucosa is an important and readily disposable source of stem like progenitor cells for neural repair, the effects of its intraspinal transplant on spinal cord injured patients have been shown. All the patients have improved their motor functions either upper extremities in tetraplegics or lower extremities in paraplegics. The side effects include a transient pain, relieved with medication, and sensory decrease [180]. Generally, the olfactory mucosa transplant is safe, without tumor or persistent neuropathic pain [181]. Neurological improvements have also been observed in spinal cord injury patients treated with intra-spinal autologous BMC graft. The best results have been obtained in patients transplanted 8 weeks before the trauma [182].

\section{Huntington's disease}

Huntington's disease (HD) is a fatal, untreated autosomal dominant characterized by CAG trinucleotide repeats located in the Huntington's gene. This neurodegenerative disorder is characterized by chorea, i.e. excessive spontaneous movements and progressive dementia. The death of the neurons of the corpus striatum causes the main symptoms [112]. At the moment, no therapies for HD exist although SCs can contrast the neurodegeneration characteristic of the disease. In a HD patient, who died 18 months after human fetal striatal tissue transplantation for a cardiovascular disease, postmortem histological analysis has showed the survival of the donor's cells. No histological evidence of rejection has been observed. The donor's fetal neural cells do not have mutated huntingtin aggregate and currently are supposed to be able to replace the damaged host neurons and reconstitute the damaged neuronal connections [183].

Several studies have emphasized safety $[184,185]$, the donor's cells survival [183] and the functional efficacy $[186,187]$ of intracerebral fetal striatal transplantation practice.

However, three cases of post-graft subdural hematomas, in late-stage HD patients, have been reported. The same authors have observed that striatal graft, in heavily 
atrophied basal ganglia, probably increases hematoma risk [188].

\section{Stroke}

The obstruction of a cerebral artery leads to focal ischemia, loss of neurons and glial cells with the consequent motor, sensory or cognitive impairments. Recent advances in thrombolysis and in neuroprotective strategies allow managing acute stroke. When drugs are administered few minutes after the injury and the damage is not severe, it is possible to restore the normal functions [112]. Interesting results are also obtained with the SC therapy.

A subarachnoidal injection of immature nervous cells and hematopoietic tissue suspension, in patients with brain stroke, have significantly improved the functional activity without serious side effects [189].

Progressively, neurological deficits have decreased in cerebral infracted patients, when treated with intravenous MSCs infusion. No adverse cell-related, serological or imaging defined effects have been observed [190].

Interesting results have been obtained with the granulocyte colony-stimulating factor (G-CSF) in the acute cerebral infarction management. G-CSF has mobilized HSCs, improving the metabolic activity and the neurologic outcomes [191].

\section{Duchenne muscular dystrophy}

Duchenne muscular dystrophy (DMD) is a severe recessive $\mathrm{X}$-linked muscular dystrophy characterized by progressive muscle degeneration, loss in ambulation, paralysis, and finally death. DMD is caused by mutations on the DMD gene, located on the $\mathrm{X}$ chromosome. DMD symptoms are principally musculoskeletal, i.e. muscle fiber and skeletal deformities, difficulties in motor skills and fatigue, but they can regard one's behavior and learning. To date, no cures for DMD are known, while treatments, such as corticosteroids, physical therapy and orthopedics appliance can control the symptoms to maximize the quality of life [192]. Recent developments in SC research suggest the possibility to replace the damaged muscle tissue.

Allogenic, combined with $\mathrm{CY}$, or autologous myoblast transplantation in DMD patients is a safe procedure. No local or systemic side effects have been reported $[193,194]$. In particular, using fluorescence in situ hybridization (FISH), myoblast allograft has showed the donor's nuclei fused with the host's nuclei and dystrophin wild type increased [195]. Therefore distrophin mRNA has been detected using polymerase chain reaction (PCR), six months after graft [196]. However, many authors have reported that myoblast injection in DMD patients do not improve their strength [194], even if the injection site, CY dose or blast number have changed [196,197]. An injection-triggered cellular immune response in the host has been discovered.
The antibodies producted are capable to fix the complement and destroy new myotubes. Probably distrophin is an antigen recognized by the host immune system [198].

\section{Heart failure}

Heart failure is commonly caused by myocardial infarction (MI). MI is the ischemic necrosis of the cardiac tissue and it is frequently triggered by severe coronary stenosis. The myocyte fall produces abnormal leftventricular remodelling the chamber dilatation and contractile dysfunction [199]. The rapid reperfusion of the infarct related coronary artery is the primary management to reduce the ischemic area and avoid the myocardic tissue damage. The percutaneous transluminal coronary angioplasty, with a stent implantation, is the gold standard method to reestablish the coronary flow. Unfortunately, angioplasty is effective only if executed rapidly and expertly, otherwise the myocardial necrosis, which starts several minutes after the coronary occlusion, commits the cardiac function [200]. Many studies suggest that SCs can improve heart function by repairing the cardiac tissue.

The major multicenter trial on MI treatment with autologous skeletal myoblast transplantation, has reported the failure of cell therapy in heart dysfunction. No improvements in the echocardiographic heart function have been underlined, neither general health has taken a turn for the worse [201]. However, other studies have described the efficacy of myoblast transplant in the ejection fraction (EF) improvement in MI patients [202,203].

Instead, AHSCT improves cardiovascular conditions in MI patients, such as ejection fraction, and it avoids harmful left ventricular remodelling [204].

In particular, intracoronary infusion of HSCs is associated with a significant reduction of the occurrence of major adverse cardiovascular events after MI, such as MI recurrence restenosis or arrhythmia $[205,206]$.

\section{Ocular surface diseases}

Ocular surface diseases are characterized by persistent epithelial defects, corneal perfusion problems, chronic inflammation, scarring and conjunctivalisation resulting in visual loss. These pathologies are associated with a limbal SC deficiency (LSCD). LSCD derives from hereditary disorders, such as aniridia, keratitis, or acquired disorders, such as Stevenson-Johnson syndrome (SJS), chemical injuries, ocular cicatricial pemphigoid, contact lens-induced keratopathy, multiple surgery or limbal region cryotherapy, neurotrophic keratopathy and peripheral ulcerative keratitis conditions [207]. Obviously, SC transplantation is the only effective therapy that can restore the ocular environment.

A study conducted on a homogeneous group of patients with limbal cell deficiency has been conducted 
using SCs obtained from the limbus of the contralateral eye. Fibrin cultures were grafted onto damaged corneas observing that: 1) fibrin-cultured limbal SCs were successful in 14 of 18 patients; 2) re-epithelialization occurred within the first week; 3 ) inflammation and vascularization regressed within the first 3-4 weeks; 4) by the first month, the corneal surface was covered by a transparent, normal-looking epithelium; 4) at 12-27 months follow-up, corneal surfaces were clinically and cytologically stable. Their visual acuity improved from light perception or counting fingers to 0.8-1.0 [208]. Limbal allograft also corrects acquired and hereditary LSCD recovering the visual activity [209-211]. It has been reported a retrospective study on endothelial rejection in central penetrating graft after a simultaneous keratolimbal allograft transplantation (KLAT) and penetrating keratoplasty (PKP) using the same donor's cornea. A third cohort of treated patients have rejected transplant. After an immunosuppressive therapy, the majority of rejects have restored the corneal clarity while in the others neovascularization has developed into the grafted limbs [212].

\section{Cartilage repair}

Osteoarthritis (OA) is a degenerative joint disease, characterized by accumulated mechanical stresses to joints and leading to the destruction of articular cartilage. A synovial fluid decrease has also been observed [213]. $\mathrm{OA}$ and peripheral joint injuries are commonly treated with interventional pain practice, exercise therapy, ultrasound or electromagnetic device after surgery, although these therapies have not proven to be a definitive solution [214-217]. SCs seem to be a promising solution to overcome OA cartilage destruction. The first autologous mesenchymal SC culture and percutaneous injection into a knee with symptomatic and radiographic degenerative joint disease has been reported and it has resulted in significant cartilage growth, decreased pain and increased joint mobility. This has significant future implications for minimally invasive treatment of osteoarthritis and meniscal injury treated with percutaneous injection of autologous MSCs expanded ex-vivo has been reported [218].

\section{Liver disease}

Cirrhosis is a progressive liver function loss caused by fibrous scar tissue replacement of normal parenchyma. Cirrhosis is commonly caused by alcoholism, hepatitis B and $C$ and fatty liver disease, but there are many other possible causes. Cirrhosis is generally irreversible and treatments are generally focused on preventing its progression and complications. Only liver transplant can revert the pathological condition if there is a terminally ill patient [219]. SC therapy can contrast liver degeneration and block cirrhosis progression.
AHSC infusion in cirrhotic patients has improved liver parameters, such as transaminase, bilirubin decrease and albumin increase [220,221]. After infusion, proliferation indexes, such as alpha fetoprotein and proliferating cell nuclear antigen (PCNA), have significantly increased, suggesting that HSCs can enhance and accelerate hepatic regeneration [222]. No significant side effects have been registered [223].

\section{Cancer}

\section{Renal cell cancer}

Renal cell cancer (RCC) is the most frequent kidney cancer. RCC originates in the lining of the proximal convoluted renal tubule. RCC appears as a yellowish, multilobulated tumor in the renal cortex, which frequently contains zones of necrosis, hemorrhage and scarring. The signs may include blood in the urine, loin pain, abdominal mass, anaemia, varicocele, vision abnormalities, pallor, hirsutism, constipation, hypertension, hypercalcemia, night sweats and severe weight loss. The initial treatment is commonly a radical or partial nephrectomy. Other treatment strategies, including hormone therapy, chemotherapy, and immunotherapy, have little impact on global survival $[224,225]$. HSCT can be an important tool for the management of RCC, in particular under the metastatic form.

HSCT, combined with the immunosuppressive or donor's lymphocyte infusion (DLI), can improve the general condition in metastatic RCC patients. Three factors, i.e. performance status, C-reactive protein (CRP) level and lactate dehydrogenase (LDH) level, have been found and they are significantly associated with a major success of allograft [226]. HSCT have trigged graft versus tumor (GVT) response, reducing the metastasis and reaching out the survival time [227-229].

\section{Breast cancer}

Breast cancer (BR) refers to cancers originating from the breast tissue, commonly from the inner lining of milk ducts or the lobules that supply the ducts with milk. Occasionally, BR presents as a metastatic disease with spreads in bones, liver, brain and lungs. The first evidence or subjective sign of BR is typically a lump that feels different from the rest of the breast tissue. Other symptoms can be: changes in breast size or shape, skin dimpling, nipple inversion, or spontaneous single-nipple discharge. Pain ("mastodynia") is an unreliable tool to determine the presence or absence of BR, but it may be indicative of other breast health issues. When the cancer cells invade the dermal lymphatics (small lymph vessels) in the breast skin, BR appears as a cutaneous inflammation. In this phase symptoms include pain, swelling, warmth and redness throughout the breast, as well as an orange peel texture to the skin, referred to as "peau 
d'orange". Treatment includes surgery, drugs (hormonal therapy and chemotherapy), and radiation, which are effective against non metastatic forms [230]. SCT can increase survival in patients with spreading $B R$.

A high dose chemotherapy (HDC) with SC support has improved the disease free survival in metastatic BR. However, HDC has induced serious cytotoxicities [231]. In reduced intensity conditioning regimens (RICT), allogeneic HSCT has proven to be effective in persistent and progressive metastatic $\mathrm{BR}$, decreasing relapse. Allogeneic SC transplantation with myeloablative conditioning regimens may provide cytoreduction and eradication of disease with a cancer free-graft and an immunemediated graft-versus-tumor (GVT) effect mediated by the donor's immune cells [232,233].

\section{Colorectal cancer}

Colorectal cancer (CRC) includes cancerous growths in the colon, rectum and appendix. Many CRCs are thought to arise from adenomatous polyps in the colon. These mushroom like growths are usually benign, but some may develop into cancer over time. Symptoms and signs are divided into: local ones, consisting in change in bowel habits and in frequency, such as constipation and/or diarrhea, feeling of incomplete defecation (tenesmus) and reduction in tool diameter, bloody stools or rectal bleeding, stools with mucus, black and tar-like stool (melena), bowel pain, bloating and vomiting, hematuria or pneumaturia, or smelly vaginal discharge; constitutional ones i.e. weight loss, anemia, dizziness, fatigue and palpitations; metastatic ones, i.e. liver metastases, causing Jaundice, pain in the abdomen, liver enlargement and blood clots in veins and arteries. Surgery is the usual therapy and, in many cases, is followed by chemotherapy [234-236]. The gastrointestinal tract is a target of GVHD in transplants and, therefore, CRC, might be treated by allogeneic SCT. Four cases of metastatic CRC, undergoing reduced-intensity SC transplantation (RIST), have been reported. No significant graft toxicities have been registered. CRC markers have decreased in three patients after allograft. Three patients died of disease progression, but postmortem examination has showed a macroscopic metastatic lesion disappearance [237]. The patients with progressing metastatic CRC, treated with RIST, have showed relevant results in terms of tumor response. Even metastatic CRC need intense GVT to eradicate spreading tumor cells. Allogeneic SCT is likely to have trigged the generation of anti-neoplastic T cells [238-240].

\section{Ovarian cancer}

Ovarian cancer (OC) is a cancerous growth arising from different parts of the ovary. Commonly, OC arises from the outer lining of the ovary, but also from the Fallopian tube or egg cells. OC is characterized by non-specific symptoms and, in early stages, it is associated with abdominal distension. Many women with OC report one or more non-specific symptoms, such as an abdominal pain or discomfort, an abdominal mass, bloating, back pain, urinary urgency, constipation, tiredness, and some specific symptoms, such as pelvic pain, abnormal vaginal bleeding or involuntary weight loss. There can be a build-up of fluid (ascites) in the abdominal cavity. A surgical treatment may be sufficient for malignant tumors that are well-differentiated and confined to the ovary. An addition of chemotherapy may be required for the most aggressive tumors that are confined to the ovary. For patients with an advanced disease, a surgical reduction is combined with a standard chemotherapy regimen. Some studies describe the feasibility of the combination of chemotherapy with SCT [241].

Allogeneic HSCT, associated with chemotherapy in advanced $\mathrm{OC}$, treatment has induced variable effects. When SCs infusion trigger GVT, it is possible to control the disease progression [242,243]. However, GVT does not occur frequently. No serious side effects have been registered [244,245].

\section{Lung cancer (LC)}

LC is characterized by an uncontrolled cell growth in the lung tissue. Frequently LC rises from the epithelial cells. The small cell lung carcinoma (SCLC) is the most frequent lung carcinoma. The symptoms can result from the local growth of the tumor (coughing up blood, shortness of breath and chest pain), a spread to the nearby areas (hoarseness of voice, shortness of breath, difficulty in swallowing, swelling of the face and hands), a distant spread (the spread to the brain can cause headache, blurring of vision, nausea, vomiting, and weakness of any limb, a spread to the vertebral column which can cause back pain, a spread to the spinal cord which can cause paralysis, a spread to the bone that may lead to bone pain and a spread to the liver possibly causing pain in the right upper part of the abdomen), paraneoplastic syndromes, or a combination of them. Possible treatments are surgery, chemotherapy, and radiotherapy [246]. An addition of SCT can improve the survival rate and avoid relapses. AHSCT has been frequently combined with chemotherapy in SCLC treatment. The reason is that HSCs drastically reduce the chemotherapy side effects, in particular myeloablation [247-249]. Probably, HSCs may also induce therapeutic effects contrasting the tumor directly [250]. In SCLC, HSCs trigger GVT and increase the survival rate.

\section{Leukemia}

Leukemia is the uncontrolled proliferation of the myeloid or lymphoid blood line and the consequential blast 
accumulation in the BM. Leukemia can be classified in acute myeloid leukemia (AML), chronic myeloid leukemia (CML), acute lymphoblastic leukemia (ALL) and chronic lymphocytic leukemia (CLL). Leukemia is caused by a mutation in the gene involved in the cell proliferation. The first signs and symptoms of leukemia are nonspecific and they include fatigue, malaise, and abnormal bleeding, excessive bruising, weakness, reduced exercise tolerance, weight loss, bone or joint pain, infection and fever, abdominal pain or "fullness", enlarged spleen, lymph nodes and liver,. Moreover a high white blood cell count is detectable. Chemotherapy is the initial treatment of choice, but only with the substitution of the malignant blast with the normal SCs, leukemia can be eradicated [251-256].

Many studies indicate allogenic RIST as an important procedure to achieve a complete remission in patients with leukemia, especially if a human leukocyte antigen compatible donor is employed [257-265]. GVHD is the major limiting factor for successful transplantation, but its frequency is sensibly reduced if compared to the first treatment $[266,267]$. The mortality rate has also decreased significantly [268].

\section{Guidelines For Scs Application}

SCs transplantation in human patients must ensure safety and therapeutic efficacy. Preclinical studies aim at providing persuasive evidence, in an appropriate in vitro and/or animal model, which supports the likelihood of a relevant positive clinical outcome. Preclinical testing in animal models, whenever feasible, is especially important for SC based approaches because SCs can act through multiple mechanisms. Physiological integration and long-lived tissue reconstitution are hallmarks of SC based therapeutics for many disease applications. Animal models will be important to assess possible adverse effects of implanted cellular products. The need for animal model is especially strong in the case of extensive ex vivo manipulation of cells and/or when the cells have been derived from pluripotent SCs.

It should be acknowledged, however, that preclinical assays, including studies in animal models, may provide limited insight into how transplanted human cells will behave in human recipients due to the context dependent nature of the cell behavior and recipient's immune response. These uncertainties must be borne in mind during the independent peer review of the preclinical data. Only when the compelling preclinical data are available, careful and incremental testing in patients is justified. Preclinical studies must be subject to rigorous and independent peer review and regulatory oversight prior to the initiation of the clinical trials, in order to ensure that the performance of the clinical studies is scientifically and medically warranted. Because new and unforeseen safety concerns may arise with the clinical translation, frequent interaction, between preclinical and clinical investigators, is strongly encouraged. The clinical trials of SC based interventions must follow internationally accepted principles governing the ethical conduct of the clinical research and the protection of the human subjects. Key requirements include regulatory oversight, peer review by an expert panel independent of the investigators and sponsors, fair subject selection, informed consent and patient monitoring. However, there is a number of important SC related issues that merit a special attention [269]. The guidelines concerning the preclinical studies (animal model), clinical studies have been summarized in the "Guidelines for the Clinical Translation of Stem Cells" published in 2008.

\section{Conclusions}

This review shows the most interesting clinical trials in SC biology and regenerative medicine [270-272]. Promising results have been described in disorders, such as diabetes [273] and neurodegenerative diseases [274,275], where SCs graft can reestablish one or more deficit cellular lineages and, generally, a healthy state. Notably, many clinical studies have underlined the immunomodulatory effect of SCs in autoimmune diseases, such as multiple sclerosis [275], organ transplants [276] and in uncontrolled immune-inflammatory reactions [277-279]. Probably, SCs induce immune suppression and inhibit proliferation of alloreactive T cells [280]. Moreover, SCs are at the core of the huge framework of cellular therapy and are going to be used in the gene therapy [281,282] or as scaffolds in SCNT [109]. An interesting cell type is the induced pluripotent stem cell (iPSC) [283]. iPSCs are artificial cells derived from non pluripotent cells, typically adult somatic cells through the induction of a "forced" expression of specific genes.

iPSCs have been regarded as the most promising way to create SCs. However the use of iPSCs has raised concerns. The iPSCs are easily created by modulating the human genome to ectopically express transcriptional factors. Since their overexpression has been associated with tumorigenesis $[284,285]$, there is a risk that the differentiated cells might also be tumorigenic when transplanted into patients. The insertion of transgenes into functional genes of the human genome can be detrimental [286]. Furthermore, although the transcription factors are mostly silenced following reprogramming, it has been reported that residual transgene expression may be responsible for some of the differences between ESCs and iPSCs such as the altered differentiation potential of iPSCs into functional cell types [287]. There are a few ways of creating iPSCs, i.e. genomic modification, protein introduction, and treatment with chemical 
reagents $[288,289]$. iPSCs research has to be conducted keeping in mind ethical, legal, and social issues [290].

These cells may be used to construct disease models and to screen effective and safe drugs, as well as to treat patients through the cell transplantation therapy [281]. However, the validity of these predictions will depend on the benefits obtained on the ongoing phase II and III human clinical trials. In the meantime, new candidate small molecules and bioactives will be identified using SC assays in the high-throughput screening that will impact on SC mobilization broaden the horizons of regenerative medicine. It has been proposed that centenarians and supercentenarians (aged 110 years or more) may present an unprecedented opportunity to explore the possibilities of SCs that have proven their value over time. These SCs should be studied to determine their developmental potential, mutational load, telomere lengths, and markers of "stemness" [291]. In conclusion, beyond the great enthusiasm for new treatment perspectives, an heavy investigational work is still in progress to develop specific SCs related pharmacology. In fact new drugs are urgently needed to assist SCs in vitro/in vivo differentiation and full tissue/organ integration and recovery. As far as CNS related diseases (cerebrovascular accidents and spinal traumatic lesions) are concerned, the role of autologous cytokines induced by SCs infusion has to be deeply investigated and may represent, in the future, a new treatment perspective.

\footnotetext{
Abbreviations

(ADSC): Adipose Tissue-Derived Stromal Cell; (ASC): Adult Stem Cell; (ALL): Acute Lymphoblastic Leukemia; (AML): Acute Myeloid Leukemia; (ASL): Amyotrophic Lateral Sclerosis; (AD): Autoimmune Diseases; (AHSCT): Autologous HSCT; (BM): Bone Marrow; (BR): Breast Cancer; (BOOP): Bronchiolitis Obliterans Organizing Pneumonia; (CNS): Central Nervous System; (CML): Chronic Myeloid Leukemia; (CLL): Chronic Lymphocytic Leukemia; (CRC): Colorectal Cancer; (CRP): C-Reactive Protein; (CY): Cyclophosphamide; (DM): Diabetes Mellitus; (DMARD): Disease-Modifying Anti-Rheumatic Drug; (DLI): Donor Lymphocyte Infusion; (DMD): Duchenne Muscular Dystrophy; (EF): Ejection Fraction; (EC): Embryonic cell; (EGC): Embryonic Germ Cell; (ESC): Embryonic Stem Cell; (EBMT): European Bone Marrow Transplantation; (FSC): Fetal Stem Cell; (GVHD): Graft Versus Host Disease; (GVT): Graft Versus Tumor; (HSC): Haematopoietic Stem Cell; (HDC): High-Dose Chemotherapy; (HSCT): HSC Transplantation; (h-AD-MSC): Human Adipose-Tissue-Derived insulin-making Mesenchymal SCs; (HD): Huntington's Disease; (IHA): Immune Haemolytic Anemia; (ITP): Immune Thrombocytopenia Purpura; (iPSC): Induced Pluripotent Stem Cell; (ICM): Inner Cell Mass; (JIA): Juvenile Idiopathic Arthritis; (KLAT): Keratolimbal Allograft Transplantation; (LDH): Lactate Dehydrogenase; (LONIPC): LateOnset Non-Infectious Pulmonary Complications; (LSCD): Limbal SC Deficiency; (LC): Lung Cancer; (MHC): Major Histocompatability Complex; (MSC): Mesenchimal Stem Cell; (MS): Multiple Sclerosis; (MI): Myocardial Infarction; (OB): Obliterative Bronchiolitis; (OA): Osteoarthritis; (OC): Ovarian Cancer; (PD): Parkinson's Disease; (PCR): Polymerase Chain Reaction; (PPMS): Primary Progressive MS; (PCNA): Proliferating Cell Nuclear Antigen; (RIST): Reduced-Intensity Stem-Cell Transplantation; (RICT): Reduced-Intensity Conditioning Regimens; (REB): Research Ethics Board; (RA): Rheumatoid Arthritis; (RCC): Renal Cell Cancer; (SPMS): Secondary Progressive MS; (SCNT): Somatic Cell Nuclear Transfer; (SCLC): Small Cell Lung Carcinoma; (SC): Stem Cell; (SCOC): Stem Cell Oversight Committee; (SF): Synovial Fluid; (SLE): Systemic Lupus Erythematosus; (SSc): Systemic Sclerosis; (UCE): Umbilical
}

Cord Epithelium; (UCB): Umbilical Cord Blood; (UC-HS): Umbilical Cord Hematopoietic; (UC-MS): Umbilical Cord Mesenchymal; (VOD): VenoOcclusive Disease;

\section{Aknowledgements}

This review was not supported by grants. The authors hereby certify that all work contained in this review is original work of $\mathrm{DL}, \mathrm{Tl}$ and $\mathrm{BP}$. All the information taken from other articles, including tables and pictures, have been referenced in the "Bibliography" section. The authors claim full responsibility for the contents of the article.

\section{Author details}

'Department of Nephrology, Dialysis and Transplantation, University of Modena and Reggio Emilia Medical School, Modena, Italy. ${ }^{2}$ Department of Biological and Biomedical Sciences, Glasgow Caledonian University, Glasgow, UK. ${ }^{3}$ Department of General Surgery and Surgical Specialties, University of Modena and Reggio Emilia Medical School, Surgical Clinic, Modena, Italy.

\section{Authors' contributions}

The authors, namely $\mathrm{DL}, \mathrm{TI}$ and $\mathrm{BP}$, contributed equally to this work. All authors read and approved the final manuscript.

\section{Competing interests}

The authors declare that they have no competing interests.

Received: 26 October 2010 Accepted: 17 January 2011

Published: 17 January 2011

\section{References}

1. Pittenger MF, Mackay AM, Beck SC, Jaiswal RK, Douglas R, Mosca JD, Moorman MA, Simonetti DW, Craig S, Marshak DR: Multilineage potential of adult human mesenchymal stem cells. Science 1999, 284(5411):143-147.

2. Mayhall EA, Paffett-Lugassy N, Zon LI: The clinical potential of stem cells. Curr Opin Cell Biol 2004, 16(6):713-720.

3. Fortier LA: Stem cells: classifications, controversies, and clinical applications. Vet Surg 2005, 34(5):415-423.

4. Zhong W: Timing cell-fate determination during asymmetric cell divisions. Curr Opin Neurobiol 2008, 18(5):472-478.

5. Doe CQ: Neural stem cells: balancing self-renewal with differentiation. Development 2008, 135(9):1575-1587.

6. Knoblich JA: Mechanisms of asymmetric stem cell division. Cell 2008, 132(4):583-597.

7. Zhong W, Chia W: Neurogenesis and asymmetric cell division. Curr Opin Neurobiol 2008, 18(1):4-11.

8. Baksh D, Song L, Tuan RS: Adult mesenchymal stem cells: characterization, differentiation, and application in cell and gene therapy. J Cell Mol Med 2004, 8(3):301-316.

9. Barry FP, Murphy JM: Mesenchymal stem cells: clinical applications and biological characterization. Int J Biochem Cell Biol 2004, 36(4):568-584.

10. Thomson JA, Itskovitz-Eldor J, Shapiro SS, Waknitz MA, Swiergiel JJ, Marshall VS, Jones JM: Embryonic stem cell lines derived from human blastocysts. Science 1998, 282(5391):1145-1147.

11. Baharvand H, Ashtiani SK, Valojerdi MR, Shahverdi A, Taee A, Sabour D: Establishment and in vitro differentiation of a new embryonic stem cell line from human blastocyst. Differentiation 2004, 72(5):224-229.

12. Ladurner $P$, Rieger $R$, Baguna J: Spatial distribution and differentiation potential of stem cells in hatchlings and adults in the marine platyhelminth macrostomum sp.: a bromodeoxyuridine analysis. Dev Biol 2000, 226(2):231-241.

13. Fang TC, Alison MR, Wright NA, Poulsom R: Adult stem cell plasticity: will engineered tissues be rejected? Int J Exp Pathol 2004, 85(3):115-124.

14. Pera MF, Reubinoff B, Trounson A: Human embryonic stem cells. J Cell Sci 2000, 113(Pt 1):5-10

15. Pessina A, Gribaldo L: The key role of adult stem cells: therapeutic perspectives. Curr Med Res Opin 2006, 22(11):2287-2300.

16. Gucciardo L, Lories R, Ochsenbein-Kolble N, Done E, Zwijsen A, Deprest J: Fetal mesenchymal stem cells: isolation, properties and potential use in perinatology and regenerative medicine. BJOG 2009, 116(2):166-172.

17. Blau HM, Brazelton TR, Weimann JM: The evolving concept of a stem cell: entity or function? Cell 2001, 105(7):829-841. 
18. Joshi D, Behari M: Neuronal stem cells. Neurol India 2003, 51(3):323-328.

19. Fan J, Varshney RR, Ren L, Cai D, Wang DA: Synovium-derived mesenchymal stem cells: a new cell source for musculoskeletal regeneration. Tissue Eng Part B Rev 2009, 15(1):75-86.

20. Voltarelli JC, Couri CE, Stracieri AB, Oliveira MC, Moraes DA, Pieroni F, Coutinho M, Malmegrim KC, Foss-Freitas MC, Simoes BP, et al: Autologous nonmyeloablative hematopoietic stem cell transplantation in newly diagnosed type 1 diabetes mellitus. JAMA 2007, 297(14):1568-1576.

21. Sangwan VS, Fernandes M, Bansal AK, Vemuganti GK, Rao GN: Early results of penetrating keratoplasty following limbal stem cell transplantation. Indian J Ophthalmol 2005, 53(1):31-35.

22. Rosa SB, Voltarelli JC, Chies JA, Pranke P: The use of stem cells for the treatment of autoimmune diseases. Braz J Med Biol Res 2007, 40(12):1579-1597.

23. Kallis $Y N$, Alison MR, Forbes SJ: Bone marrow stem cells and liver disease. Gut 2007, 56(5):716-724.

24. Varanou $A$, Page CP, Minger SL: Human embryonic stem cells and lung regeneration. Br J Pharmacol 2008, 155(3):316-325

25. Nieto $Y$, Jones RB, Shpall EJ: Stem-cell transplantation for the treatment of advanced solid tumors. Springer Semin Immunopathol 2004, 26(12):31-56.

26. Filip S, Mokry J, Horacek J, English D: Stem cells and the phenomena of plasticity and diversity: a limiting property of carcinogenesis. Stem Cells Dev 2008, 17(6):1031-1038.

27. Vicente-Duenas C, Gutierrez de Diego J, Rodriguez FD, Jimenez R, Cobaleda C: The role of cellular plasticity in cancer development. Curr Med Chem 2009, 16(28):3676-3685.

28. Reddy P, Arora M, Guimond M, Mackall CL: GVHD: a continuing barrier to the safety of allogeneic transplantation. Biol Blood Marrow Transplant 2009, 15(1 Suppl):162-168

29. Zarzeczny A, Caulfield T: Emerging ethical, legal and social issues associated with stem cell research \& and the current role of the moral status of the embryo. Stem Cell Rev 2009, 5(2):96-101.

30. Wobus AM, Boheler KR: Embryonic stem cells: prospects for developmental biology and cell therapy. Physiol Rev 2005, 85(2):635-678.

31. Oligny LL: Human molecular embryogenesis: an overview. Pediatr Dev Pathol 2001, 4(4):324-343.

32. Talbot NC, Powell AM, Rexroad CE Jr: In vitro pluripotency of epiblasts derived from bovine blastocysts. Mol Reprod Dev 1995, 42(1):35-52

33. Odorico JS, Kaufman DS, Thomson JA: Multilineage differentiation from human embryonic stem cell lines. Stem Cells 2001, 19(3):193-204.

34. Sjogren A, Hardarson T, Andersson $K$, Caisander G, Lundquist M, Wikland M, Semb H, Hamberger L: Human blastocysts for the development of embryonic stem cells. Reprod Biomed Online 2004, 9(3):326-329.

35. Cowan CA, Klimanskaya I, McMahon J, Atienza J, Witmyer J, Zucker JP, Wang S, Morton CC, McMahon AP, Powers D, et al: Derivation of embryonic stem-cell lines from human blastocysts. N Engl J Med 2004, 350(13):1353-1356

36. Rosler ES, Fisk GJ, Ares X, Irving J, Miura T, Rao MS, Carpenter MK: Longterm culture of human embryonic stem cells in feeder-free conditions. Dev Dyn 2004, 229(2):259-274.

37. Fujioka T, Yasuchika K, Nakamura Y, Nakatsuji N, Suemori H: A simple and efficient cryopreservation method for primate embryonic stem cells. Int $J$ Dev Biol 2004, 48(10):1149-1154.

38. Zhou CQ, Mai QY, Li T, Zhuang GL: Cryopreservation of human embryonic stem cells by vitrification. Chin Med J (Engl) 2004, 117(7):1050-1055.

39. Reubinoff BE, Pera MF, Vajta G, Trounson AO: Effective cryopreservation of human embryonic stem cells by the open pulled straw vitrification method. Hum Reprod 2001, 16(10):2187-2194.

40. Hayflick L, Moorhead PS: The serial cultivation of human diploid cell strains. Exp Cell Res 1961, 25:585-621.

41. Campisi J: From cells to organisms: can we learn about aging from cells in culture? Exp Gerontol 2001, 36(4-6):607-618

42. Wright WE, Shay JW: Historical claims and current interpretations of replicative aging. Nat Biotechnol 2002, 20(7):682-688

43. D'lppolito G, Schiller PC, Ricordi C, Roos BA, Howard GA: Age-related osteogenic potential of mesenchymal stromal stem cells from human vertebral bone marrow. J Bone Miner Res 1999, 14(7):1115-1122.

44. Brook FA, Gardner RL: The origin and efficient derivation of embryonic stem cells in the mouse. Proc Natl Acad Sci USA 1997, 94(11):5709-5712.
45. O'Donoghue K, Fisk NM: Fetal stem cells. Best Pract Res Clin Obstet Gynaecol 2004, 18(6):853-875

46. Gallacher L, Murdoch B, Wu D, Karanu F, Fellows F, Bhatia M: Identification of novel circulating human embryonic blood stem cells. Blood 2000, 96(5):1740-1747.

47. Fortier LA, Nixon AJ, Williams J, Cable CS: Isolation and chondrocytic differentiation of equine bone marrow-derived mesenchymal stem cells. Am J Vet Res 1998, 59(9):1182-1187.

48. Deasy BM, Li Y, Huard J: Tissue engineering with muscle-derived stem cells. Curr Opin Biotechnol 2004, 15(5):419-423.

49. Zuk PA, Zhu M, Mizuno H, Huang J, Futrell JW, Katz AJ, Benhaim P, Lorenz HP, Hedrick MH: Multilineage cells from human adipose tissue: implications for cell-based therapies. Tissue Eng 2001, 7(2):211-228.

50. De Bari C, Dell'Accio F, Tylzanowski P, Luyten FP: Multipotent mesenchymal stem cells from adult human synovial membrane. Arthritis Rheum 2001, 44(8):1928-1942.

51. Zarnett R, Salter RB: Periosteal neochondrogenesis for biologically resurfacing joints: its cellular origin. Can J Surg 1989, 32(3):171-174.

52. Wong MH: Regulation of intestinal stem cells. J Investig Dermatol Symp Proc 2004, 9(3):224-228.

53. Blanpain C, Lowry WE, Geoghegan A, Polak L, Fuchs E: Self-renewal, multipotency, and the existence of two cell populations within an epithelial stem cell niche. Cell 2004, 118(5):635-648.

54. Miura M, Gronthos S, Zhao M, Lu B, Fisher LW, Robey PG, Shi S: SHED: stem cells from human exfoliated deciduous teeth. Proc Natl Acad Sci USA 2003, 100(10):5807-5812.

55. McKay RD: Stem cell biology and neurodegenerative disease. Philos Trans $R$ Soc Lond B Biol Sci 2004, 359(1445):851-856.

56. Young HE, Ceballos EM, Smith JC, Mancini ML, Wright RP, Ragan BL, Bushell I, Lucas PA: Pluripotent mesenchymal stem cells reside within avian connective tissue matrices. In Vitro Cell Dev Biol Anim 1993, 29A(9):723-736

57. Smart N, Riley PR: The stem cell movement. Circ Res 2008 102(10):1155-1168.

58. Behrstock S, Ebert AD, Klein S, Schmitt M, Moore JM, Svendsen CN: Lesioninduced increase in survival and migration of human neural progenitor cells releasing GDNF. Cell Transplant 2008, 17(7):753-762.

59. Wognum AW, Eaves AC, Thomas TE: Identification and isolation of hematopoietic stem cells. Arch Med Res 2003, 34(6):461-475.

60. van Bekkum DW: Bone marrow transplantation. Transplant Proc 1977, 9(1):147-154

61. Mimeault M, Batra SK: Recent progress on tissue-resident adult stem cell biology and their therapeutic implications. Stem Cell Rev 2008, 4(1):27-49.

62. Chen FH, Rousche KT, Tuan RS: Technology Insight: adult stem cells in cartilage regeneration and tissue engineering. Nat Clin Pract Rheumatol 2006, 2(7):373-382.

63. Bianco P, Robey PG, Simmons PJ: Mesenchymal stem cells: revisiting history, concepts, and assays. Cell Stem Cell 2008, 2(4):313-319.

64. Menicanin D, Bartold PM, Zannettino AC, Gronthos S: Genomic profiling of mesenchymal stem cells. Stem Cell Rev 2009, 5(1):36-50.

65. Alison MR, Poulsom R, Jeffery R, Dhillon AP, Quaglia A, Jacob J, Novelli M, Prentice G, Williamson J, Wright NA: Hepatocytes from non-hepatic adult stem cells. Nature 2000, 406(6793):257.

66. Ortiz LA, Gambelli F, McBride C, Gaupp D, Baddoo M, Kaminski N, Phinney DG: Mesenchymal stem cell engraftment in lung is enhanced in response to bleomycin exposure and ameliorates its fibrotic effects. Proc Natl Acad Sci USA 2003, 100(14):8407-8411.

67. Brazelton TR, Rossi FM, Keshet Gl, Blau HM: From marrow to brain: expression of neuronal phenotypes in adult mice. Science 2000, 290(5497):1775-1779.

68. Chen FH, Tuan RS: Mesenchymal stem cells in arthritic diseases. Arthritis Res Ther 2008, 10(5):223.

69. Tan SC, Pan WX, Ma G, Cai N, Leong KW, Liao K: Viscoelastic behaviour of human mesenchymal stem cells. BMC Cell Biol 2008, 9:40.

70. Boquest AC, Noer A, Collas P: Epigenetic programming of mesenchymal stem cells from human adipose tissue. Stem Cell Rev 2006, 2(4):319-329.

71. Mizuno H: Adipose-derived stem cells for tissue repair and regeneration: ten years of research and a literature review. J Nippon Med Sch 2009, 76(2):56-66.

72. Meirelles Lda S, Nardi NB: Methodology, biology and clinical applications of mesenchymal stem cells. Front Biosci 2009, 14:4281-4298. 
73. Ruhil S, Kumar V, Rathee P: Umbilical cord stem cell: an overview. Curr Pharm Biotechnol 2009, 10(3):327-334

74. Mizoguchi M, lkeda S, Suga Y, Ogawa H: Expression of cytokeratins and cornified cell envelope-associated proteins in umbilical cord epithelium: a comparative study of the umbilical cord, amniotic epithelia and fetal skin. J Invest Dermatol 2000, 115(1):133-134.

75. Hoyes AD: Ultrastructure of the epithelium of the human umbilical cord. $J$ Anat 1969, 105(Pt 1):149-162.

76. Mizoguchi M, Suga Y, Sanmano B, Ikeda S, Ogawa H: Organotypic culture and surface plantation using umbilical cord epithelial cells: morphogenesis and expression of differentiation markers mimicking cutaneous epidermis. J Dermatol Sci 2004, 35(3):199-206.

77. Sanmano B, Mizoguchi M, Suga Y, Ikeda S, Ogawa H: Engraftment of umbilical cord epithelial cells in athymic mice: in an attempt to improve reconstructed skin equivalents used as epithelial composite. J Dermatol Sci 2005, 37(1):29-39.

78. Ruetze M, Gallinat S, Lim IJ, Chow E, Phan TT, Staeb F, Wenck H, Deppert W, Knott A: Common features of umbilical cord epithelial cells and epidermal keratinocytes. J Dermatol Sci 2008, 50(3):227-231.

79. Mihu CM, Mihu D, Costin N, Rus Ciuca D, Susman S, Ciortea R: Isolation and characterization of stem cells from the placenta and the umbilical cord. Rom J Morphol Embryol 2008, 49(4):441-446.

80. In 't Anker PS, Scherjon SA, Kleijburg-van der Keur C, de Groot-Swings GM Claas FH, Fibbe WE, Kanhai HH: Isolation of mesenchymal stem cells of fetal or maternal origin from human placenta. Stem Cells 2004, 22(7):1338-1345.

81. Chien JW, Duncan S, Williams KM, Pavletic SZ: Bronchiolitis Obliterans Syndrome After Allogeneic Hematopoietic Stem Cell Transplantation An Increasingly Recognized Manifestation of Chronic Graft-versus-Host Disease. Biol Blood Marrow Transplant 2010, 16(1 Suppl):S106-14.

82. Moghadam KG, Marghoob B, Alimoghadam K, Shirani S, Ghavamzadeh A: Bronchiolitis obliterans following hematopoietic stem cell transplantation. Hematol Oncol Stem Cell Ther 2010, 3(2):100-101.

83. Miyagawa-Hayashino A, Sonobe M, Kubo T, Yoshizawa A, Date $H_{\text {, }}$ Manabe T: Non-specific interstitial pneumonia as a manifestation of graft-versus-host disease following pediatric allogeneic hematopoietic stem cell transplantation. Pathol Int 2010, 60(2):137-142.

84. Bryant DH: Obliterative bronchiolitis in haematopoietic stem cell transplantation: can it be treated? Eur Respir J 2005, 25(3):402-404.

85. Park M, Koh KN, Kim BE, Im HJ, Seo JJ: Clinical features of late onset noninfectious pulmonary complications following pediatric allogeneic hematopoietic stem cell transplantation. Clin Transplant 2010.

86. Yoshihara S, Yanik G, Cooke KR, Mineishi S: Bronchiolitis obliterans syndrome (BOS), bronchiolitis obliterans organizing pneumonia (BOOP), and other late-onset noninfectious pulmonary complications following allogeneic hematopoietic stem cell transplantation. Biol Blood Marrow Transplant 2007, 13(7):749-759.

87. Majeski El, Paintlia MK, Lopez AD, Harley RA, London SD, London L: Respiratory reovirus $1 / L$ induction of intraluminal fibrosis, a model of bronchiolitis obliterans organizing pneumonia, is dependent on T lymphocytes. Am J Pathol 2003, 163(4):1467-1479.

88. Ditschkowski M, Elmaagacli AH, Trenschel R, Peceny R, Koldehoff M, Schulte C, Beelen DW: T-cell depletion prevents from bronchiolitis obliterans and bronchiolitis obliterans with organizing pneumonia after allogeneic hematopoietic stem cell transplantation with related donors. Haematologica 2007, 92(4):558-561.

89. Kanda Y, Takahashi T, Imai Y, Miyagawa K, Ohishi N, Oka T, Chiba S, Hirai H, Yazaki Y: Bronchiolitis obliterans organizing pneumonia after syngeneic bone marrow transplantation for acute lymphoblastic leukemia. Bone Marrow Transplant 1997, 19(12):1251-1253.

90. Cordier JF: Bronchiolitis obliterans organizing pneumonia. Semin Respir Crit Care Med 2000, 21(2):135-146.

91. Patriarca F, Skert C, Bonifazi F, Sperotto A, Fili C, Stanzani M, Zaja F, Cerno M, Geromin A, Bandini G, et al: Effect on survival of the development of late-onset non-infectious pulmonary complications after stem cell transplantation. Haematologica 2006, 91(9):1268-1272.

92. Ferrara JL, Levine JE, Reddy P, Holler E: Graft-versus-host disease. Lancet 2009, 373(9674):1550-1561

93. Ferrara JL, Deeg HJ: Graft-versus-host disease. N Engl J Med 1991, 324(10):667-674.
94. Goker H, Haznedaroglu IC, Chao NJ: Acute graft-vs-host disease: pathobiology and management. Exp Hematol 2001, 29(3):259-277.

95. Nevo S, Enger C, Swan V, Wojno KJ, Fuller AK, Altomonte V, Braine HG, Noga SJ, Vogelsang GB: Acute bleeding after allogeneic bone marrow transplantation: association with graft versus host disease and effect on survival. Transplantation 1999, 67(5):681-689.

96. Fujii N, Takenaka K, Shinagawa K, Ikeda K, Maeda Y, Sunami K, Hiramatsu Y, Matsuo K, Ishimaru F, Niiya K, et al: Hepatic graft-versus-host disease presenting as an acute hepatitis after allogeneic peripheral blood stem cell transplantation. Bone Marrow Transplant 2001, 27(9):1007-1010.

97. Lee JW, Joachim Deeg H: Prevention of chronic GVHD. Best Pract Res Clin Haematol 2008, 21(2):259-270

98. Lee SJ: New approaches for preventing and treating chronic graftversus-host disease. Blood 2005, 105(11):4200-4206.

99. Martin PJ, Weisdorf D, Przepiorka D, Hirschfeld S, Farrell A, Rizzo JD, Foley R, Socie G, Carter S, Couriel D, et al: National Institutes of Health Consensus Development Project on Criteria for Clinical Trials in Chronic Graftversus-Host Disease: VI. Design of Clinical Trials Working Group report. Biol Blood Marrow Transplant 2006, 12(5):491-505.

100. Rimkus C: Acute complications of stem cell transplant. Semin Oncol Nurs 2009, 25(2):129-138.

101. Tabbara IA, Zimmerman K, Morgan C, Nahleh Z: Allogeneic hematopoietic stem cell transplantation: complications and results. Arch Intern Med 2002, 162(14):1558-1566.

102. Skotnicki $A B$, Krawczyk J: Veno-occlusive disease-an important complication in hematopoietic cells transplantation. Przegl Lek 2001, 58(11):995-999.

103. Lee SH, Yoo KH, Sung KW, Koo HH, Kwon YJ, Kwon MM, Park HJ, Park BK, Kim YY, Park JA, et al: Hepatic veno-occlusive disease in children after hematopoietic stem cell transplantation: incidence, risk factors, and outcome. Bone Marrow Transplant 2010, 45(8):1287-1293.

104. Cesaro S, Pillon M, Talenti E, Toffolutti T, Calore E, Tridello G, Strugo L, Destro R, Gazzola MV, Varotto S, et al: A prospective survey on incidence, risk factors and therapy of hepatic veno-occlusive disease in children after hematopoietic stem cell transplantation. Haematologica 2005, 90(10):1396-1404.

105. Shah MS, Jeevangi NK, Joshi A, Khattry N: Late-onset hepatic venoocclusive disease post autologous peripheral stem cell transplantation successfully treated with oral defibrotide. I Cancer Res Ther 2009, 5(4):312-314.

106. Lakshminarayanan S, Sahdev I, Goyal M, Vlachos A, Atlas M, Lipton JM: Low incidence of hepatic veno-occlusive disease in pediatric patients undergoing hematopoietic stem cell transplantation attributed to a combination of intravenous heparin, oral glutamine, and ursodiol at a single transplant institution. Pediatr Transplant 2010, 14(5):618-621.

107. Pittenger MF, Martin BJ: Mesenchymal stem cells and their potential as cardiac therapeutics. Circ Res 2004, 95(1):9-20.

108. Di Nicola M, Carlo-Stella C, Magni M, Milanesi M, Longoni PD, Matteucci P, Grisanti S, Gianni AM: Human bone marrow stromal cells suppress Tlymphocyte proliferation induced by cellular or nonspecific mitogenic stimuli. Blood 2002, 99(10):3838-3843.

109. Alberio R, Campbell KH, Johnson AD: Reprogramming somatic cells into stem cells. Reproduction 2006, 132(5):709-720.

110. Fairchild PJ, Cartland S, Nolan KF, Waldmann H: Embryonic stem cells and the challenge of transplantation tolerance. Trends Immunol 2004, 25(9):465-470.

111. Amariglio N, Hirshberg A, Scheithauer BW, Cohen Y, Loewenthal R, Trakhtenbrot L, Paz N, Koren-Michowitz M, Waldman D, Leider-Trejo L, et al: Donor-derived brain tumor following neural stem cell transplantation in an ataxia telangiectasia patient. PLoS Med 2009, 6(2):e1000029

112. Lindvall O, Kokaia Z: Stem cells for the treatment of neurological disorders. Nature 2006, 441(7097):1094-1096.

113. Lindvall O, Kokaia Z, Martinez-Serrano A: Stem cell therapy for human neurodegenerative disorders-how to make it work. Nat Med 2004, 10 Suppl:S42-50.

114. Bjorklund LM, Sanchez-Pernaute R, Chung S, Andersson T, Chen IY, McNaught KS, Brownell AL, Jenkins BG, Wahlestedt C, Kim KS, et al: Embryonic stem cells develop into functional dopaminergic neurons after transplantation in a Parkinson rat model. Proc Natl Acad Sci USA 2002, 99(4):2344-2349. 
115. Arnhold S, Lenartz D, Kruttwig K, Klinz FJ, Kolossov E, Hescheler J, Sturm V, Andressen C, Addicks K: Differentiation of green fluorescent proteinlabeled embryonic stem cell-derived neural precursor cells into Thy-1positive neurons and glia after transplantation into adult rat striatum. $J$ Neurosurg 2000, 93(6):1026-1032.

116. Werbowetski-Ogilvie TE, Bosse M, Stewart M, Schnerch A, Ramos-Mejia V, Rouleau A, Wynder T, Smith MJ, Dingwall S, Carter T, et al: Characterization of human embryonic stem cells with features of neoplastic progression. Nat Biotechnol 2009, 27(1):91-97.

117. Crooks VA, Snyder J: Regulating medical tourism. Lancet 2010, 376(9751):1465-1466.

118. Barclay E: Stem-cell experts raise concerns about medical tourism. Lancet 2009, 373(9667):883-884

119. Lau D, Ogbogu U, Taylor B, Stafinski T, Menon D, Caulfield T: Stem cell clinics online: the direct-to-consumer portrayal of stem cell medicine. Cell Stem Cell 2008, 3(6):591-594.

120. Pepper MS: Cell-based therapy - navigating troubled waters. S Afr Med J 2010, 100(5):286, 288.

121. Woo P: Systemic juvenile idiopathic arthritis: diagnosis, management, and outcome. Nat Clin Pract Rheumatol 2006, 2(1):28-34.

122. Ringe J, Sittinger M: Tissue engineering in the rheumatic diseases. Arthritis Res Ther 2009, 11(1):211.

123. Hayward K, Wallace CA: Recent developments in anti-rheumatic drugs in pediatrics: treatment of juvenile idiopathic arthritis. Arthritis Res Ther 2009, 11(1):216.

124. Snowden JA, Passweg J, Moore JJ, Milliken S, Cannell P, Van Laar J, Verburg R, Szer J, Taylor K, Joske D, et al: Autologous hemopoietic stem cell transplantation in severe rheumatoid arthritis: a report from the EBMT and ABMTR. J Rheumatol 2004, 31(3):482-488.

125. Moore J, Brooks P, Milliken S, Biggs J, Ma D, Handel M, Cannell P, Will R, Rule $S$, Joske D, et al: A pilot randomized trial comparing CD34-selected versus unmanipulated hemopoietic stem cell transplantation for severe, refractory rheumatoid arthritis. Arthritis Rheum 2002, 46(9):2301-2309.

126. De Kleer IM, Brinkman DM, Ferster A, Abinun M, Quartier P, Van Der Net J, Ten Cate R, Wedderburn LR, Horneff G, Oppermann J, et al: Autologous stem cell transplantation for refractory juvenile idiopathic arthritis: analysis of clinical effects, mortality, and transplant related morbidity. Ann Rheum Dis 2004, 63(10):1318-1326.

127. Jallouli M, Frigui M, Hmida MB, Marzouk S, Kaddour N, Bahloul Z: Clinical and immunological manifestations of systemic lupus erythematosus: study on 146 south Tunisian patients. Saudi J Kidney Dis Transp/ 2008, 19(6):1001-1008.

128. loannou Y, Isenberg DA: Current concepts for the management of systemic lupus erythematosus in adults: a therapeutic challenge. Postgrad Med J 2002, 78(924):599-606.

129. Traynor AE, Barr WG, Rosa RM, Rodriguez J, Oyama Y, Baker S, Brush M, Burt RK: Hematopoietic stem cell transplantation for severe and refractory lupus. Analysis after five years and fifteen patients. Arthritis Rheum 2002, 46(11):2917-2923.

130. Burt RK, Traynor A, Statkute L, Barr WG, Rosa R, Schroeder J, Verda L, Krosnjar N, Quigley K, Yaung K, et al: Nonmyeloablative hematopoietic stem cell transplantation for systemic lupus erythematosus. JAMA 2006, 295(5):527-535.

131. Goldblatt F, Isenberg DA: New therapies for systemic lupus erythematosus. Clin Exp Immunol 2005, 140(2):205-212.

132. Compston A, Coles A: Multiple sclerosis. Lancet 2008, 372(9648):1502-1517.

133. Katsara M, Matsoukas J, Deraos G, Apostolopoulos V: Towards immunotherapeutic drugs and vaccines against multiple sclerosis. Acta Biochim Biophys Sin (Shanghai) 2008, 40(7):636-642.

134. Ebers GC: Natural history of primary progressive multiple sclerosis. Mult Scler 2004, 10(Suppl 1):S8-13, discussion S13-15.

135. Saccardi R, Mancardi GL, Solari A, Bosi A, Bruzzi P, Di Bartolomeo P, Donelli A, Filippi M, Guerrasio A, Gualandi F, et al: Autologous HSCT for severe progressive multiple sclerosis in a multicenter trial: impact on disease activity and quality of life. Blood 2005, 105(6):2601-2607.

136. Fassas A, Passweg JR, Anagnostopoulos A, Kazis A, Kozak T, Havrdova E, Carreras E, Graus F, Kashyap A, Openshaw H, et al: Hematopoietic stem cell transplantation for multiple sclerosis. A retrospective multicenter study. J Neurol 2002, 249(8):1088-1097.

137. Fassas A, Anagnostopoulos A, Kazis A, Kapinas K, Sakellari I, Kimiskidis V, Smias C, Eleftheriadis N, Tsimourtou V: Autologous stem cell transplantation in progressive multiple sclerosis-an interim analysis of efficacy. J Clin Immunol 2000, 20(1):24-30.

138. Mezey E, Chandross KJ, Harta G, Maki RA, McKercher SR: Turning blood into brain: cells bearing neuronal antigens generated in vivo from bone marrow. Science 2000, 290(5497):1779-1782.

139. Lim IG, Schrieber L: Management of systemic sclerosis. Isr Med Assoc J 2002, 4(11 Suppl):953-957.

140. Akerkar SM, Bichile LS: Therapeutic options for systemic sclerosis. Indian J Dermatol Venereol Leprol 2004, 70(2):67-75.

141. Tyndall A, Black C, Finke J, Winkler J, Mertlesmann R, Peter HH, Gratwohl A: Treatment of systemic sclerosis with autologous haemopoietic stem cell transplantation. Lancet 1997, 349(9047):254.

142. van den Hoogen FH, van de Putte LB: Treatment of systemic sclerosis. Curr Opin Rheumatol 1994, 6(6):637-641.

143. Martini A, Maccario R, Ravelli A, Montagna D, De Benedetti F, Bonetti F, Viola S, Zecca M, Perotti C, Locatelli F: Marked and sustained improvement two years after autologous stem cell transplantation in a girl with systemic sclerosis. Arthritis Rheum 1999, 42(4):807-811.

144. Binks M, Passweg JR, Furst D, McSweeney P, Sullivan K, Besenthal C, Finke J, Peter HH, van Laar J, Breedveld FC, et al: Phase I/II trial of autologous stem cell transplantation in systemic sclerosis: procedure related mortality and impact on skin disease. Ann Rheum Dis 2001, 60(6):577-584

145. Farge D, Marolleau JP, Zohar S, Marjanovic Z, Cabane J, Mounier N, Hachulla E, Philippe P, Sibilia J, Rabian C, et al: Autologous bone marrow transplantation in the treatment of refractory systemic sclerosis: early results from a French multicentre phase I-II study. Br J Haematol 2002, 119(3):726-739.

146. McSweeney PA, Nash RA, Sullivan KM, Storek J, Crofford LJ, Dansey R, Mayes MD, McDonagh KT, Nelson JL, Gooley TA, et al: High-dose immunosuppressive therapy for severe systemic sclerosis: initial outcomes. Blood 2002, 100(5):1602-1610.

147. Farge D, Passweg J, van Laar JM, Marjanovic Z, Besenthal C, Finke J, Peter HH, Breedveld FC, Fibbe WE, Black C, et al: Autologous stem cell transplantation in the treatment of systemic sclerosis: report from the EBMT/EULAR Registry. Ann Rheum Dis 2004, 63(8):974-981.

148. Rampton DS: Management of Crohn's disease. BMJ 1999, 319(7223):1480-1485

149. Cassinotti A, Annaloro C, Ardizzone S, Onida F, Della Volpe A, Clerici M, Usardi P, Greco S, Maconi G, Porro GB, et al: Autologous haematopoietic stem cell transplantation without CD34+ cell selection in refractory Crohn's disease. Gut 2008, 57(2):211-217.

150. Oyama Y, Craig RM, Traynor AE, Quigley K, Statkute L, Halverson A, Brush M, Verda L, Kowalska B, Krosnjar N, et al: Autologous hematopoietic stem cell transplantation in patients with refractory Crohn's disease. Gastroenterology 2005, 128(3):552-563.

151. Burt RK, Traynor A, Oyama Y, Craig R: High-dose immune suppression and autologous hematopoietic stem cell transplantation in refractory Crohn disease. Blood 2003, 101(5):2064-2066.

152. Stasi R, Provan D: Management of immune thrombocytopenic purpura in adults. Mayo Clin Proc 2004, 79(4):504-522

153. Huhn RD, Fogarty PF, Nakamura R, Read EJ, Leitman SF, Rick ME, Kimball J, Greene A, Hansmann K, Gratwohl A, et al: High-dose cyclophosphamide with autologous lymphocyte-depleted peripheral blood stem cell (PBSC) support for treatment of refractory chronic autoimmune thrombocytopenia. Blood 2003, 101(1):71-77.

154. Urban C, Lackner H, Sovinz P, Benesch M, Schwinger W, Dornbusch HJ, Moser A: Successful unrelated cord blood transplantation in a 7-year-old boy with Evans syndrome refractory to immunosuppression and double autologous stem cell transplantation. Eur J Haematol 2006, 76(6):526-530.

155. Riechsteiner G, Speich R, Schanz U, Russi EW, Weder W, Boehler A: Haemolytic anaemia after lung transplantation: an immune-mediated phenomenon? Swiss Med Wkly 2003, 133(9-10):143-147.

156. Pratt G, Kinsey SE: Remission of severe, intractable autoimmune haemolytic anaemia following matched unrelated donor transplantation. Bone Marrow Transplant 2001, 28(8):791-793.

157. Sallah S, Wan JY, Hanrahan LR: Future development of lymphoproliferative disorders in patients with autoimmune hemolytic anemia. Clin Cancer Res 2001, 7(4):791-794.

158. Seeliger S, Baumann M, Mohr M, Jurgens H, Frosch M, Vormoor J: Autologous peripheral blood stem cell transplantation and anti-B-cell 
directed immunotherapy for refractory auto-immune haemolytic anaemia. Eur J Pediatr 2001, 160(8):492-496.

159. Passweg JR, Rabusin M, Musso M, Beguin Y, Cesaro S, Ehninger G, Espigado I, Iriondo A, Jost L, Koza V, et al: Haematopoetic stem cell transplantation for refractory autoimmune cytopenia. Br J Haematol 2004, 125(6):749-755.

160. Eisenbarth GS: Update in type 1 diabetes. J Clin Endocrinol Metab 2007, 92(7):2403-2407.

161. Aiello LP, Gardner TW, King GL, Blankenship G, Cavallerano JD, Ferris FL, Klein R: Diabetic retinopathy. Diabetes Care 1998, 21(1):143-156.

162. Sima AA, Zhang W, Grunberger G: Type 1 diabetic neuropathy and Cpeptide. Exp Diabesity Res 2004, 5(1):65-77.

163. Ingberg CM, Palmer M, Schvarcz E, Aman J: Prevalence of urinary tract symptoms in long-standing type 1 diabetes mellitus. Diabetes Metab 1998, 24(4):351-354.

164. Couri CE, Oliveira MC, Stracieri AB, Moraes DA, Pieroni F, Barros GM, Madeira MI, Malmegrim KC, Foss-Freitas MC, Simoes BP, et al: C-peptide levels and insulin independence following autologous nonmyeloablative hematopoietic stem cell transplantation in newly diagnosed type 1 diabetes mellitus. JAMA 2009, 301(15):1573-1579.

165. Snarski E, Torosian T, Paluszewska M, Urbanowska E, Milczarczyk A, Jedynasty K, Franek E, Jedrzejczak WW: Alleviation of exogenous insulin requirement in type 1 diabetes mellitus after immunoablation and transplantation of autologous hematopoietic stem cells. Pol Arch Med Wewn 2009, 119(6):422-426.

166. Trivedi HL, Vanikar AV, Thakker U, Firoze A, Dave SD, Patel CN, Patel JV, Bhargava $A B$, Shankar $V$ : Human adipose tissue-derived mesenchymal stem cells combined with hematopoietic stem cell transplantation synthesize insulin. Transplant Proc 2008, 40(4):1135-1139.

167. Wijesekera LC, Leigh PN: Amyotrophic lateral sclerosis. Orphanet J Rare Dis 2009, 4:3.

168. Janson CG, Ramesh TM, During MJ, Leone P, Heywood J: Human intrathecal transplantation of peripheral blood stem cells in amyotrophic lateral sclerosis. J Hematother Stem Cell Res 2001, 10(6):913-915.

169. Mazzini L, Ferrero I, Luparello V, Rustichelli D, Gunetti M, Mareschi K, Testa L, Stecco A, Tarletti R, Miglioretti M, et al: Mesenchymal stem cell transplantation in amyotrophic lateral sclerosis: A Phase I clinical trial. Exp Neurol 2010, 223(1):229-37.

170. Mazzini L, Fagioli F, Boccaletti R, Mareschi K, Oliveri G, Olivieri C, Pastore I, Marasso R, Madon E: Stem cell therapy in amyotrophic lateral sclerosis: a methodological approach in humans. Amyotroph Lateral Scler Other Motor Neuron Disord 2003, 4(3):158-161.

171. Martinez HR, Gonzalez-Garza MT, Moreno-Cuevas JE, Caro E, GutierrezJimenez E, Segura JJ: Stem-cell transplantation into the frontal motor cortex in amyotrophic lateral sclerosis patients. Cytotherapy 2009, 11(1):26-34.

172. Papadeas ST, Maragakis NJ: Advances in stem cell research for Amyotrophic Lateral Sclerosis. Curr Opin Biotechnol 2009, 20(5):545-551.

173. Astradsson A, Cooper O, Vinuela A, Isacson O: Recent advances in cellbased therapy for Parkinson disease. Neurosurg Focus 2008, 24(3-4):E6

174. Weintraub D, Comella CL, Horn S: Parkinson's disease-Part 2: Treatment of motor symptoms. Am J Manag Care 2008, 14(2 Suppl):S49-58.

175. Hagell P, Schrag A, Piccini P, Jahanshahi M, Brown R, Rehncrona S, Widner $H$, Brundin P, Rothwell JC, Odin P, et al: Sequential bilateral transplantation in Parkinson's disease: effects of the second graft. Brain 1999, 122(Pt 6):1121-1132.

176. Brundin $P$, Pogarell $O$, Hagell P, Piccini P, Widner H, Schrag A, Kupsch A Crabb L, Odin P, Gustavii B, et al: Bilateral caudate and putamen grafts of embryonic mesencephalic tissue treated with lazaroids in Parkinson's disease. Brain 2000, 123(Pt 7):1380-1390.

177. Freed CR, Greene PE, Breeze RE, Tsai WY, DuMouchel W, Kao R, Dillon S, Winfield H, Culver S, Trojanowski JQ, et al: Transplantation of embryonic dopamine neurons for severe Parkinson's disease. N Engl J Med 2001, 344(10):710-719.

178. Hauser RA, Freeman TB, Snow BJ, Nauert M, Gauger L, Kordower JH, Olanow CW: Long-term evaluation of bilateral fetal nigral transplantation in Parkinson disease. Arch Neurol 1999, 56(2):179-187.

179. Olanow CW, Goetz CG, Kordower JH, Stoessl AJ, Sossi V, Brin MF, Shannon KM, Nauert GM, Perl DP, Godbold J, et al: A double-blind controlled trial of bilateral fetal nigral transplantation in Parkinson's disease. Ann Neurol 2003, 54(3):403-414.
180. Lima C, Pratas-Vital J, Escada P, Hasse-Ferreira A, Capucho C, Peduzzi JD: Olfactory mucosa autografts in human spinal cord injury: a pilot clinical study. J Spinal Cord Med 2006, 29(3):191-203, discussion 204-196.

181. Mackay-Sim A, Feron F, Cochrane J, Bassingthwaighte L, Bayliss C, Davies W, Fronek P, Gray C, Kerr G, Licina P, et al: Autologous olfactory ensheathing cell transplantation in human paraplegia: a 3-year clinical trial. Brain 2008, 131(Pt 9):2376-2386.

182. Yoon SH, Shim YS, Park YH, Chung JK, Nam JH, Kim MO, Park HC, Park SR, Min BH, Kim EY, et al: Complete spinal cord injury treatment using autologous bone marrow cell transplantation and bone marrow stimulation with granulocyte macrophage-colony stimulating factor: Phase I/II clinical trial. Stem Cells 2007, 25(8):2066-2073.

183. Freeman TB, Cicchetti F, Hauser RA, Deacon TW, Li XJ, Hersch SM, Nauert GM, Sanberg PR, Kordower JH, Saporta S, et al: Transplanted fetal striatum in Huntington's disease: phenotypic development and lack of pathology. Proc Natl Acad Sci USA 2000, 97(25):13877-13882.

184. Kopyov OV, Jacques S, Lieberman A, Duma CM, Eagle KS: Safety of intrastriatal neurotransplantation for Huntington's disease patients. Exp Neurol 1998, 149(1):97-108.

185. Rosser AE, Barker RA, Harrower T, Watts C, Farrington M, Ho AK Burnstein RM, Menon DK, Gillard JH, Pickard J, et al: Unilateral transplantation of human primary fetal tissue in four patients with Huntington's disease: NEST-UK safety report ISRCTN no 36485475. J Neurol Neurosurg Psychiatry 2002, 73(6):678-685.

186. Gaura V, Bachoud-Levi AC, Ribeiro MJ, Nguyen JP, Frouin V, Baudic S, Brugieres $P$, Mangin JF, Boisse MF, Palfi $S$, et al: Striatal neural grafting improves cortical metabolism in Huntington's disease patients. Brain 2004, 127(Pt 1):65-72.

187. Palfi $S$, Nguyen JP, Brugieres $P$, Le Guerinel $C$, Hantraye $P$, Remy $P$, Rostaing S, Defer GL, Cesaro P, Keravel Y, et al: MRI-stereotactical approach for neural grafting in basal ganglia disorders. Exp Neurol 1998, 150(2):272-281.

188. Hauser RA, Sandberg PR, Freeman TB, Stoessl AJ: Bilateral human fetal striatal transplantation in Huntington's disease. Neurology 2002, 58(11):1704, author reply 1704 .

189. Rabinovich SS, Seledtsov VI, Banul NV, Poveshchenko OV, Senyukov W, Astrakov SV, Samarin DM, Taraban VY: Cell therapy of brain stroke. Bull Exp Biol Med 2005, 139(1):126-128.

190. Bang OY, Lee JS, Lee PH, Lee G: Autologous mesenchymal stem cell transplantation in stroke patients. Ann Neurol 2005, 57(6):874-882.

191. Shyu WC, Lin SZ, Lee CC, Liu DD, Li H: Granulocyte colony-stimulating factor for acute ischemic stroke: a randomized controlled trial. CMAJ 2006, 174(7):927-933.

192. Yiu EM, Kornberg AJ: Duchenne muscular dystrophy. Neurol India 2008 56(3):236-247.

193. Torrente Y, Belicchi M, Marchesi C, Dantona G, Cogiamanian F, Pisati F, Gavina M, Giordano R, Tonlorenzi R, Fagiolari G, et al: Autologous transplantation of muscle-derived CD133+ stem cells in Duchenne muscle patients. Cell Transplant 2007, 16(6):563-577.

194. Neumeyer AM, Cros D, McKenna-Yasek D, Zawadzka A, Hoffman EP, Pegoraro E, Hunter RG, Munsat TL, Brown RH Jr: Pilot study of myoblast transfer in the treatment of Becker muscular dystrophy. Neurology 1998, 51(2):589-592.

195. Gussoni E, Blau HM, Kunkel LM: The fate of individual myoblasts after transplantation into muscles of DMD patients. Nat Med 1997, 3(9):970-977.

196. Miller RG, Sharma KR, Pavlath GK, Gussoni E, Mynhier M, Lanctot AM, Greco CM, Steinman L, Blau HM: Myoblast implantation in Duchenne muscular dystrophy: the San Francisco study. Muscle Nerve 1997, 20(4):469-478.

197. Mendell JR, Kissel JT, Amato AA, King W, Signore L, Prior TW, Sahenk Z, Benson S, McAndrew PE, Rice R, et al: Myoblast transfer in the treatment of Duchenne's muscular dystrophy. N Engl I Med 1995, 333(13):832-838

198. Tremblay JP, Malouin F, Roy R, Huard J, Bouchard JP, Satoh A, Richards CL: Results of a triple blind clinical study of myoblast transplantations without immunosuppressive treatment in young boys with Duchenne muscular dystrophy. Cell Transplant 1993, 2(2):99-112.

199. Vincent $R$ : Advances in the early diagnosis and management of acute myocardial infarction. J Accid Emerg Med 1996, 13(2):74-79. 
200. Goldman LE, Eisenberg MJ: Identification and management of patients with failed thrombolysis after acute myocardial infarction. Ann Intern Med 2000, 132(7):556-565.

201. Menasche P, Alfieri O, Janssens S, McKenna W, Reichenspurner $H$ Trinquart L, Vilquin JT, Marolleau JP, Seymour B, Larghero J, et al: The Myoblast Autologous Grafting in Ischemic Cardiomyopathy (MAGIC) trial: first randomized placebo-controlled study of myoblast transplantation. Circulation 2008, 117(9):1189-1200.

202. Hagege AA, Marolleau JP, Vilquin JT, Alheritiere A, Peyrard S, Duboc D, Abergel E, Messas E, Mousseaux E, Schwartz K, et al: Skeletal myoblast transplantation in ischemic heart failure: long-term follow-up of the first phase I cohort of patients. Circulation 2006, 114(1 Suppl):1108-113.

203. Siminiak T, Kalawski R, Fiszer D, Jerzykowska O, Rzezniczak J, Rozwadowska N, Kurpisz M: Autologous skeletal myoblast transplantation for the treatment of postinfarction myocardial injury: phase I clinical study with 12 months of follow-up. Am Heart J 2004, 148(3):531-537.

204. Schachinger V, Assmus B, Erbs S, Elsasser A, Haberbosch W, Hambrecht R, Yu J, Corti R, Mathey DG, Hamm CW, et al: Intracoronary infusion of bone marrow-derived mononuclear cells abrogates adverse left ventricular remodelling post-acute myocardial infarction: insights from the reinfusion of enriched progenitor cells and infarct remodelling in acute myocardial infarction (REPAIR-AMI) trial. Eur J Heart Fail 2009, 11(10):973-979.

205. Schachinger V, Erbs S, Elsasser A, Haberbosch W, Hambrecht R, Holschermann H, Yu J, Corti R, Mathey DG, Hamm CW, et al: Intracoronary bone marrow-derived progenitor cells in acute myocardial infarction. $\mathrm{N}$ Engl J Med 2006, 355(12):1210-1221.

206. Wollert KC, Meyer GP, Lotz J, Ringes-Lichtenberg S, Lippolt P, Breidenbach C, Fichtner S, Korte T, Hornig B, Messinger D, et al: Intracoronary autologous bone-marrow cell transfer after myocardial infarction: the BOOST randomised controlled clinical trial. Lancet 2004 364(9429):141-148

207. Ang LP, Tan DT: Ocular surface stem cells and disease: current concepts and clinical applications. Ann Acad Med Singapore 2004, 33(5):576-580.

208. Rama P, Bonini S, Lambiase A, Golisano O, Paterna P, De Luca M, Pellegrini G: Autologous fibrin-cultured limbal stem cells permanently restore the corneal surface of patients with total limbal stem cell deficiency. Transplantation 2001, 72(9):1478-1485.

209. Daya SM, Ilari FA: Living related conjunctival limbal allograft for the treatment of stem cell deficiency. Ophthalmology 2001, 108(1):126-133, discussion 133-124.

210. Ilari L, Daya SM: Long-term outcomes of keratolimbal allograft for the treatment of severe ocular surface disorders. Ophthalmology 2002 109(7):1278-1284.

211. Solomon A, Ellies $P$, Anderson DF, Touhami A, Grueterich M, Espana EM, Ti SE, Goto E, Feuer WJ, Tseng SC: Long-term outcome of keratolimbal allograft with or without penetrating keratoplasty for total limbal stem cell deficiency. Ophthalmology 2002, 109(6):1159-1166.

212. Shimazaki J, Maruyama F, Shimmura S, Fujishima H, Tsubota K: Immunologic rejection of the central graft after limbal allograft transplantation combined with penetrating keratoplasty. Cornea 2001 20(2):149-152.

213. Mobasheri A, Csaki C, Clutterbuck AL, Rahmanzadeh M, Shakibaei M: Mesenchymal stem cells in connective tissue engineering and regenerative medicine: applications in cartilage repair and osteoarthritis therapy. Histol Histopathol 2009, 24(3):347-366.

214. McNair PJ, Simmonds MA, Boocock MG, Larmer PJ: Exercise therapy for the management of osteoarthritis of the hip joint: a systematic review. Arthritis Res Ther 2009, 11(3):R98.

215. Srbely JZ: Ultrasound in the management of osteoarthritis: part I: a review of the current literature. J Can Chiropr Assoc 2008, 52(1):30-37.

216. Barron MC, Rubin BR: Managing osteoarthritic knee pain. J Am Osteopath Assoc 2007, 107(10 Suppl 6):ES21-27.

217. Santaguida PL, Hawker GA, Hudak PL, Glazier R, Mahomed NN, Kreder HJ, Coyte PC, Wright JG: Patient characteristics affecting the prognosis of total hip and knee joint arthroplasty: a systematic review. Can J Surg 2008, 51(6):428-436.

218. Centeno CJ, Busse D, Kisiday J, Keohan C, Freeman M, Karli D: Increased knee cartilage volume in degenerative joint disease using percutaneously implanted, autologous mesenchymal stem cells. Pain Physician 2008, 11(3):343-353
219. Schuppan D, Afdhal NH: Liver cirrhosis. Lancet 2008, 371(9615):838-851.

220. Pai M, Zacharoulis D, Milicevic MN, Helmy S, Jiao LR, Levicar N, Tait P, Scott M, Marley SB, Jestice K, et al: Autologous infusion of expanded mobilized adult bone marrow-derived CD34+ cells into patients with alcoholic liver cirrhosis. Am J Gastroenterol 2008, 103(8):1952-1958.

221. Lyra AC, Soares MB, da Silva LF, Fortes MF, Silva AG, Mota AC, Oliveira SA, Braga EL, de Carvalho WA, Genser B, et al: Feasibility and safety of autologous bone marrow mononuclear cell transplantation in patients with advanced chronic liver disease. World J Gastroenterol 2007, 13(7):1067-1073

222. am Esch JS, Knoefel WT, Klein M, Ghodsizad A, Fuerst G, Poll LW, Piechaczek C, Burchardt ER, Feifel N, Stoldt V, et al: Portal application of autologous CD133+ bone marrow cells to the liver: a novel concept to support hepatic regeneration. Stem Cells 2005, 23(4):463-470.

223. Terai S, Ishikawa T, Omori K, Aoyama K, Marumoto Y, Urata Y, Yokoyama Y, Uchida K, Yamasaki T, Fujii Y, et al: Improved liver function in patients with liver cirrhosis after autologous bone marrow cell infusion therapy. Stem Cells 2006, 24(10):2292-2298

224. Heldwein FL, McCullough TC, Souto CA, Galiano M, Barret E: Localized renal cell carcinoma management: an update. Int Braz J Urol 2008 , 34(6):676-689, discussion 689-690.

225. Oudard S, George D, Medioni J, Motzer R: Treatment options in renal cell carcinoma: past, present and future. Ann Oncol 2007, 18(Suppl 10):x25-31.

226. Peccatori J, Barkholt L, Demirer T, Sormani MP, Bruzzi P, Ciceri F, Zambelli A Da Prada GA, Pedrazzoli P, Siena S, et al: Prognostic factors for survival in patients with advanced renal cell carcinoma undergoing nonmyeloablative allogeneic stem cell transplantation. Cancer 2005, 104(10):2099-2103.

227. Barkholt L, Bregni M, Remberger M, Blaise D, Peccatori J, Massenkeil G, Pedrazzoli P, Zambelli A, Bay JO, Francois S, et al: Allogeneic haematopoietic stem cell transplantation for metastatic renal carcinoma in Europe. Ann Oncol 2006, 17(7):1134-1140.

228. Artz AS, Van Besien K, Zimmerman T, Gajewski TF, Rini Bl, Hu HS, Stadler WM, Vogelzang NJ: Long-term follow-up of nonmyeloablative allogeneic stem cell transplantation for renal cell carcinoma: The University of Chicago Experience. Bone Marrow Transplant 2005, 35(3):253-260.

229. Childs R, Chernoff A, Contentin N, Bahceci E, Schrump D, Leitman S, Read EJ, Tisdale J, Dunbar C, Linehan WM, et al: Regression of metastatic renal-cell carcinoma after nonmyeloablative allogeneic peripheral-blood stem-cell transplantation. N Engl J Med 2000, 343(11):750-758.

230. Singletary SE: Breast cancer management: the road to today. Cancer 2008 113(7 Suppl):1844-1849.

231. Biron $P$, Durand $M$, Roche $H$, Delozier T, Battista C, Fargeot $P$, Spaeth D, Bachelot T, Poiget E, Monnot F, et al: Pegase 03: a prospective randomized phase III trial of FEC with or without high-dose thiotepa, cyclophosphamide and autologous stem cell transplantation in first-line treatment of metastatic breast cancer. Bone Marrow Transplant 2008, 41(6):555-562.

232. Ueno NT, Rizzo JD, Demirer T, Cheng YC, Hegenbart U, Zhang MJ, Bregni M, Carella A, Blaise D, Bashey A, et al: Allogeneic hematopoietic cell transplantation for metastatic breast cancer. Bone Marrow Transplant 2008, 41(6):537-545.

233. Carella AM, Bregni M: Current role of allogeneic stem cell transplantation in breast cancer. Ann Oncol 2007, 18(10):1591-1593.

234. Gill S, Blackstock AW, Goldberg RM: Colorectal cancer. Mayo Clin Proc 2007, 82(1):114-129.

235. Benson AB: Epidemiology, disease progression, and economic burden of colorectal cancer. J Manag Care Pharm 2007, 13(6 Suppl C):S5-18.

236. Nagy VM: Updating the management of rectal cancer. J Gastrointestin Liver Dis 2008, 17(1):69-74.

237. Kojima R, Kami M, Hori A, Murashige N, Ohnishi M, Kim SW, Hamaki T, Kishi $Y$, Tsutsumi $Y$, Masauzi N, et al: Reduced-intensity allogeneic hematopoietic stem-cell transplantation as an immunotherapy for metastatic colorectal cancer. Transplantation 2004, 78(12):1740-1746.

238. Aglietta M, Barkholt L, Schianca FC, Caravelli D, Omazic B, Minotto C, Leone F, Hentschke P, Bertoldero G, Capaldi A, et al: Reduced-intensity allogeneic hematopoietic stem cell transplantation in metastatic colorectal cancer as a novel adoptive cell therapy approach. The European group for blood and marrow transplantation experience. Biol Blood Marrow Transplant 2009, 15(3):326-335. 
239. Hashino S, Kobayashi S, Takahata M, Onozawa M, Nakagawa M, Kawamura T, Fujisawa F, Izumiyama K, Kahata K, Kondo T, et al: Graftversus-tumor effect after reduced-intensity allogeneic hematopoietic stem cell transplantation in a patient with advanced colon cancer. Int J Clin Oncol 2008, 13(2):176-180.

240. Carnevale-Schianca F, Cignetti A, Capaldi A, Vitaggio K, Vallario A, Ricchiardi A, Sperti E, Ferraris R, Gatti M, Grignani G, et al: Allogeneic nonmyeloablative hematopoietic cell transplantation in metastatic colon cancer: tumor-specific $T$ cells directed to a tumor-associated antigen are generated in vivo during GVHD. Blood 2006, 107(9):3795-3803.

241. Schilder RJ, Boente MP, Corn BW, Lanciano RM, Young RC, Ozols RF: The management of early ovarian cancer. Oncology (Williston Park) 1995, 9(2):171-182, discussion 185-177.

242. Bay JO, Fleury J, Choufi B, Tournilhac O, Vincent C, Bailly C, Dauplat J, Viens P, Faucher C, Blaise D: Allogeneic hematopoietic stem cell transplantation in ovarian carcinoma: results of five patients. Bone Marrow Transplant 2002, 30(2):95-102.

243. Rini BI, Zimmerman T, Stadler WM, Gajewski TF, Vogelzang NJ: Allogeneic stem-cell transplantation of renal cell cancer after nonmyeloablative chemotherapy: feasibility, engraftment, and clinical results. J Clin Oncol 2002, 20(8):2017-2024.

244. Papadimitriou C, Dafni U, Anagnostopoulos A, Vlachos G, Voulgaris Z, Rodolakis A, Aravantinos G, Bamias A, Bozas G, Kiosses E, et al: High-dose melphalan and autologous stem cell transplantation as consolidation treatment in patients with chemosensitive ovarian cancer: results of a single-institution randomized trial. Bone Marrow Transplant 2008, 41(6):547-554.

245. Sarosy GA, Reed E: Autologous stem-cell transplantation in ovarian cancer: is more better? Ann Intern Med 2000, 133(7):555-556.

246. Seidenfeld J, Samson DJ, Bonnell CJ, Ziegler KM, Aronson N: Management of small cell lung cancer. Evid Rep Technol Assess (Full Rep) 2006, , 143: $1-154$.

247. Souhami RL, Hajichristou HT, Miles DW, Earl HM, Harper PG, Ash CM, Goldstone AH, Spiro SG, Geddes DM, Tobias JS: Intensive chemotherapy with autologous bone marrow transplantation for small-cell lung cancer. Cancer Chemother Pharmacol 1989, 24(5):321-325.

248. Humblet Y, Symann M, Bosly A, Delaunois L, Francis C, Machiels J, Beauduin $\mathrm{M}$, Doyen $\mathrm{C}$, Weynants $\mathrm{P}$, Longueville J, et al: Late intensification chemotherapy with autologous bone marrow transplantation in selected small-cell carcinoma of the lung: a randomized study. J Clin Oncol 1987, 5(12):1864-1873.

249. Leyvraz S, Perey L, Rosti G, Lange A, Pampallona S, Peters R, Humblet Y, Bosquee L, Pasini F, Marangolo M: Multiple courses of high-dose ifosfamide, carboplatin, and etoposide with peripheral-blood progenitor cells and filgrastim for small-cell lung cancer: A feasibility study by the European Group for Blood and Marrow Transplantation. J Clin Oncol 1999, 17(11):3531-3539.

250. Brugger W, Fetscher S, Hasse J, Frommhold H, Pressler K, Mertelsmann R, Engelhardt R, Kanz L: Multimodality treatment including early high-dose chemotherapy with peripheral blood stem cell transplantation in limited-disease small cell lung cancer. Semin Oncol 1998, 25(1 Supp 2):42-48.

251. Hoelzer D, Gokbuget N, Ottmann O, Pui CH, Relling MV, Appelbaum FR, van Dongen JJ, Szczepanski T: Acute lymphoblastic leukemia. Hematology Am Soc Hematol Educ Program 2002, 162-192.

252. Stone RM, O'Donnell MR, Sekeres MA: Acute myeloid leukemia. Hematology Am Soc Hematol Educ Program 2004, 98-117.

253. Shah NP: Medical management of CML. Hematology Am Soc Hematol EduC Program 2007, 371-375

254. Quintas-Cardama A, Cortes JE: Chronic myeloid leukemia: diagnosis and treatment. Mayo Clin Proc 2006, 81(7):973-988

255. Yee KW, O'Brien SM: Chronic lymphocytic leukemia: diagnosis and treatment. Mayo Clin Proc 2006, 81(8):1105-1129.

256. Kay NE, Hamblin TJ, Jelinek DF, Dewald GW, Byrd JC, Farag S, Lucas M, Lin T: Chronic lymphocytic leukemia. Hematology Am Soc Hematol Educ Program 2002, 193-213.

257. Fagioli F, Zecca M, Locatelli F, Lanino E, Uderzo C, Di Bartolomeo P, Berger M, Favre C, Rondelli R, Pession A, et al: Allogeneic stem cell transplantation for children with acute myeloid leukemia in second complete remission. J Pediatr Hematol Oncol 2008, 30(8):575-583.
258. Frassoni F, Gualandi F, Podesta M, Raiola AM, Ibatici A, Piaggio G, Sessarego M, Sessarego N, Gobbi M, Sacchi N, et al: Direct intrabone transplant of unrelated cord-blood cells in acute leukaemia: a phase I/II study. Lancet Oncol 2008, 9(9):831-839.

259. Ruiz-Arguelles GJ, Gomez-Almaguer D, Morales-Toquero A, GutierrezAguirre CH, Vela-Ojeda J, Garcia-Ruiz-Esparza MA, Manzano C, Karduss A, Sumoza A, de-Souza $C$, et al: The early referral for reduced-intensity stem cell transplantation in patients with $\mathrm{Ph} 1(+)$ chronic myelogenous leukemia in chronic phase in the imatinib era: results of the Latin American Cooperative Oncohematology Group (LACOHG) prospective, multicenter study. Bone Marrow Transplant 2005, 36(12):1043-1047.

260. Oehler VG, Radich JP, Storer B, Blume KG, Chauncey T, Clift R, Snyder DS, Forman SJ, Flowers ME, Martin $P$, et al: Randomized trial of allogeneic related bone marrow transplantation versus peripheral blood stem cell transplantation for chronic myeloid leukemia. Biol Blood Marrow Transplant 2005, 11(2):85-92.

261. Ohnishi K, Ino A, Kishimoto Y, Usui N, Shimazaki C, Ohtake S, Taguchi H, Yagasaki $F$, Tomonaga $M$, Hotta $T$, et al: Multicenter prospective study of interferon alpha versus allogeneic stem cell transplantation for patients with new diagnoses of chronic myelogenous leukemia. Int J Hematol 2004, 79(4):345-353.

262. Das M, Saikia TK, Advani SH, Parikh PM, Tawde S: Use of a reducedintensity conditioning regimen for allogeneic transplantation in patients with chronic myeloid leukemia. Bone Marrow Transplant 2003, 32(2):125-129.

263. Mohty M, Labopin M, Tabrizzi R, Theorin N, Fauser AA, Rambaldi A, Maertens J, Slavin S, Majolino I, Nagler A, et al: Reduced intensity conditioning allogeneic stem cell transplantation for adult patients with acute lymphoblastic leukemia: a retrospective study from the European Group for Blood and Marrow Transplantation. Haematologica 2008, 93(2):303-306.

264. Tobinai K, Takeyama K, Arima F, Aikawa K, Kobayashi T, Hanada S, Kasai M, Ogura M, Sueoka E, Mukai K, et al: Phase II study of chemotherapy and stem cell transplantation for adult acute lymphoblastic leukemia or lymphoblastic lymphoma: Japan Clinical Oncology Group Study 9004. Cancer Sci 2007, 98(9):1350-1357.

265. Isidori A, Motta MR, Tani M, Terragna C, Zinzani P, Curti A, Rizzi S, Taioli S, Giudice $V$, D'Addio A, et al: Positive selection and transplantation of autologous highly purified CD133(+) stem cells in resistant/relapsed chronic lymphocytic leukemia patients results in rapid hematopoietic reconstitution without an adequate leukemic cell purging. Biol Blood Marrow Transplant 2007, 13(10):1224-1232.

266. Grigg AP, Gibson J, Bardy PG, Reynolds J, Shuttleworth P, Koelmeyer RL, Szer J, Roberts AW, To LB, Kennedy G, et al: A prospective multicenter trial of peripheral blood stem cell sibling allografts for acute myeloid leukemia in first complete remission using fludarabinecyclophosphamide reduced intensity conditioning. Biol Blood Marrow Transplant 2007, 13(5):560-567.

267. Gutierrez-Aguirre CH, Gomez-Almaguer D, Cantu-Rodriguez OG, GonzalezLlano O, Jaime-Perez JC, Herena-Perez S, Manzano CA, Estrada-Gomez R, Gonzalez-Carrillo ML, Ruiz-Arguelles GJ: Non-myeloablative stem cell transplantation in patients with relapsed acute lymphoblastic leukemia: results of a multicenter study. Bone Marrow Transplant 2007, 40(6):535-539.

268. Dreger P, Brand R, Hansz J, Milligan D, Corradini P, Finke J, Deliliers GL, Martino R, Russell N, Van Biezen A, et al: Treatment-related mortality and graft-versus-leukemia activity after allogeneic stem cell transplantation for chronic lymphocytic leukemia using intensity-reduced conditioning. Leukemia 2003, 17(5):841-848

269. Marina Cavazzana-Calvo GC, George Q Daley, De Luca Michele, Ira J Fox, Gerstle Claude, Robert A, Goldstein GH, Katherine A High, Hyun Ok Kim, Hin Peng Lee, Ephrat Levy-Lahad, Lingsong Li BL, Daniel R Marshak, Angela McNab, Munsie Megan, Nakauchi Hiromitsu, Mahendra Rao, Carlos Simon Valles, Srivastava Alok, Sugarman Jeremy, Patrick L Taylor, Veiga Anna, Zoloth Laurie, Wong AL: Guidelines for the Clinical Translation of Stem Cells.Edited by: Research ISFSC 2008, 19.

270. Daley GQ: Stem cells: roadmap to the clinic. J Clin Invest 120(1):8-10.

271. Watt FM, Driskell RR: The therapeutic potential of stem cells. Philos Trans $R$ Soc Lond B Biol Sci 365(1537):155-163.

272. Trounson A: New perspectives in human stem cell therapeutic research. BMC Med 2009, 7:29. 
273. Kroon E, Martinson LA, Kadoya K, Bang AG, Kelly OG, Eliazer S, Young H, Richardson M, Smart NG, Cunningham J, et al: Pancreatic endoderm derived from human embryonic stem cells generates glucose-responsive insulin-secreting cells in vivo. Nat Biotechnol 2008, 26(4):443-452.

274. Preynat-Seauve O, Burkhard PR, Villard J, Zingg W, Ginovart N, Feki A, Dubois-Dauphin M, Hurst SA, Mauron A, Jaconi M, et al: Pluripotent stem cells as new drugs? The example of Parkinson's disease. Int J Pharm 2009, 381(2):113-121.

275. Burt RK, Loh Y, Cohen B, Stefoski D, Balabanov R, Katsamakis G, Oyama Y, Russell EJ, Stern J, Muraro P, et al: Autologous non-myeloablative haemopoietic stem cell transplantation in relapsing-remitting multiple sclerosis: a phase I/II study. Lancet Neurol 2009, 8(3):244-253.

276. Crop MJ, Baan CC, Korevaar SS, ljzermans JN, Alwayn IP, Weimar W, Hoogduijn MJ: Donor-derived mesenchymal stem cells suppress alloreactivity of kidney transplant patients. Transplantation 2009, 87(6):896-906

277. Troeger A, Meisel R, Moritz T, Dilloo D: Immunotherapy in allogeneic hematopoietic stem cell transplantation-not just a case for effector cells. Bone Marrow Transplant 2005, 35(Suppl 1):S59-64.

278. Le Blanc K, Frassoni F, Ball L, Locatelli F, Roelofs H, Lewis I, Lanino E, Sundberg B, Bernardo ME, Remberger M, et al: Mesenchymal stem cells for treatment of steroid-resistant, severe, acute graft-versus-host disease: a phase II study. Lancet 2008, 371(9624):1579-1586.

279. Iyer SS, Co C, Rojas M: Mesenchymal stem cells and inflammatory lung diseases. Panminerva Med 2009, 51(1):5-16.

280. Nasef A, Ashammakhi N, Fouillard L: Immunomodulatory effect of mesenchymal stromal cells: possible mechanisms. Regen Med 2008, 3(4):531-546.

281. Yamanaka S: A fresh look at iPS cells. Cell 2009, 137(1):13-17.

282. Zhou H, Wu S, Joo JY, Zhu S, Han DW, Lin T, Trauger S, Bien G, Yao S, Zhu $Y$, et al: Generation of induced pluripotent stem cells using recombinant proteins. Cell Stem Cell 2009, 4(5):381-384.

283. Yamashita JK: ES and iPS cell research for cardiovascular regeneration. Exp Cell Res 2010, 316(16):2555-2559.

284. Foster KW, Liu Z, Nail CD, Li X, Fitzgerald TJ, Bailey SK, Frost AR, Louro ID, Townes TM, Paterson AJ, et al: Induction of KLF4 in basal keratinocytes blocks the proliferation-differentiation switch and initiates squamous epithelial dysplasia. Oncogene 2005, 24(9):1491-1500.

285. Hochedlinger K, Yamada Y, Beard C, Jaenisch R: Ectopic expression of Oct4 blocks progenitor-cell differentiation and causes dysplasia in epithelial tissues. Cell 2005, 121(3):465-477.

286. Nair V: Retrovirus-induced oncogenesis and safety of retroviral vectors. Curr Opin Mol Ther 2008, 10(5):431-438,

287. Soldner F, Hockemeyer D, Beard C, Gao Q, Bell GW, Cook EG, Hargus G, Blak A, Cooper O, Mitalipova M, et al: Parkinson's disease patient-derived induced pluripotent stem cells free of viral reprogramming factors. Cell 2009, 136(5):964-977.

288. Maherali N, Hochedlinger K: Guidelines and techniques for the generation of induced pluripotent stem cells. Cell Stem Cell 2008, 3(6):595-605.

289. Tenzen T, Zembowicz F, Cowan CA: Genome modification in human embryonic stem cells. J Cell Physiol 2010, 222(2):278-281.

290. Zarzeczny A, Scott C, Hyun I, Bennett J, Chandler J, Charge S, Heine H, Isasi R, Kato K, Lovell-Badge R, et al: iPS cells: mapping the policy issues. Cell 2009, 139(6):1032-1037.

291. Lewis R, Zhdanov Rl: Centenarians as stem cell donors. Am J Bioeth 2009, 9(11):1-3.

doi:10.1186/1756-9966-30-9

Cite this article as: Lodi et al:: Stem cells in clinical practice: applications and warnings. Journal of Experimental \& Clinical Cancer Research 2011 30:9.

\section{Submit your next manuscript to BioMed Central and take full advantage of:}

- Convenient online submission

- Thorough peer review

- No space constraints or color figure charges

- Immediate publication on acceptance

- Inclusion in PubMed, CAS, Scopus and Google Scholar

- Research which is freely available for redistribution

Submit your manuscript at www.biomedcentral.com/submit 